In cooperation with the Texas Water Development Board

\title{
Evaluation of the Streamflow-Gaging Network of Texas and a Proposed Core Network
}

Water-Resources Investigations Report 01-4155

U.S. Department of the Interior

U.S. Geological Survey 
U.S. Department of the Interior

U.S. Geological Survey

\section{Evaluation of the Streamflow-Gaging Network of Texas and a Proposed Core Network}

By Raymond M. Slade, Jr., Teresa Howard, and Roberto Anaya

\section{U.S. GEOLOGICAL SURVEY}

Water-Resources Investigations Report 01-4155

In cooperation with the Texas Water Development Board

Austin, Texas

2001 


\section{U.S. DEPARTMENT OF THE INTERIOR}

Gale A. Norton, Secretary

\section{U.S. GEOLOGICAL SURVEY}

Charles G. Groat, Director

Any use of trade, product, or firm names is for descriptive purposes only and does not imply endorsement by the U.S. Government.

For additional information write to

\section{District Chief}

U.S. Geological Survey

8027 Exchange Dr.

Austin, TX 78754-4733

E-mail: dc_tx@usgs.gov

Copies of this report can be purchased from

U.S. Geological Survey

Branch of Information Services

Box 25286

Denver, CO 80225-0286

E-mail: infoservices@usgs.gov 


\section{CONTENTS}

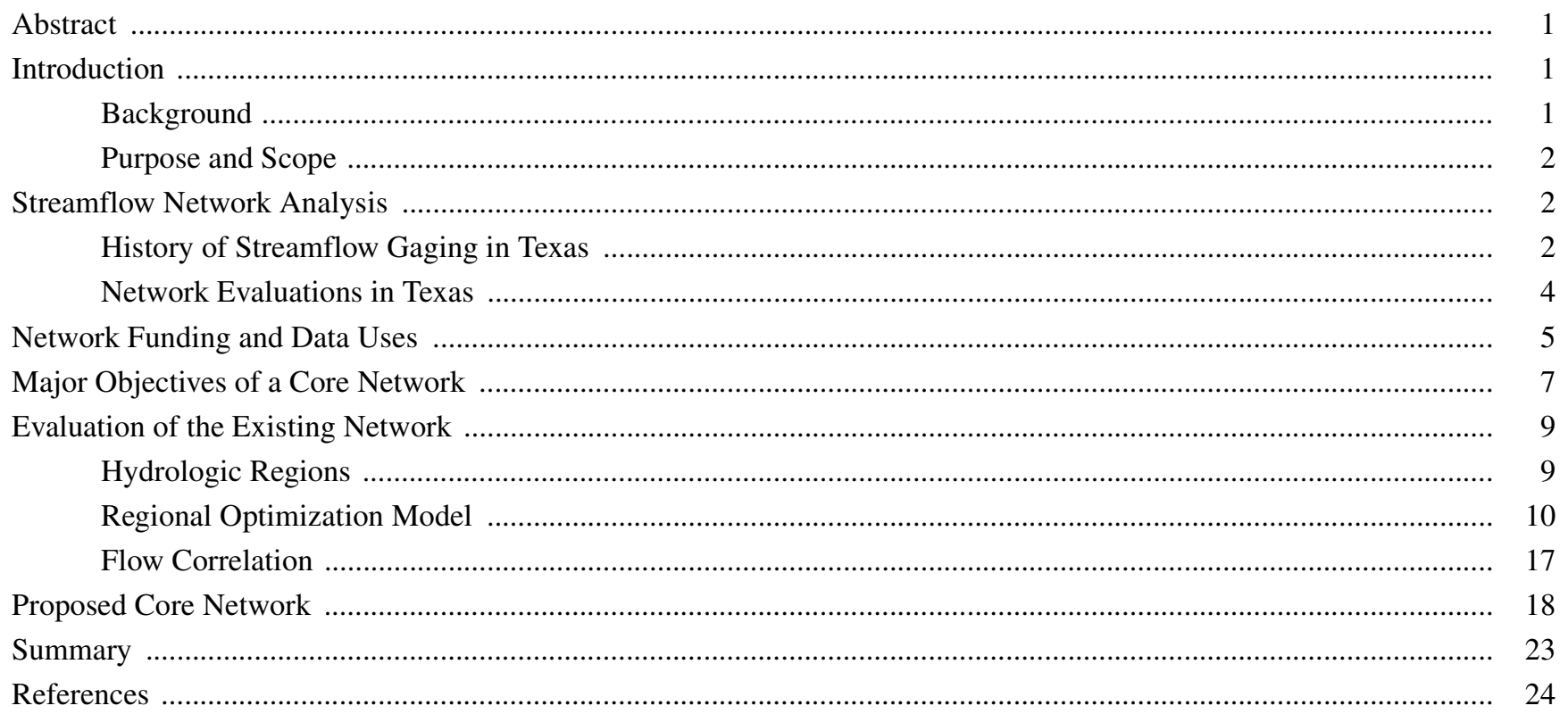

\section{PLATE}

(Plate is in pocket)

1. Map showing locations of stations in the proposed core streamflow network of Texas

\section{FIGURES}

1. Graph showing number of daily mean and annual peak streamflow stations in Texas, 1898-1996 ................. 3

2. Map showing locations of active and discontinued daily streamflow stations, October 1,1998 ........................ 4

3. Map showing hydrologic regions and major basins of Texas .............................................................. 8

4-9. Graphs showing relation between mean sampling error, number of streamflow-gaging stations, and planning horizon for:

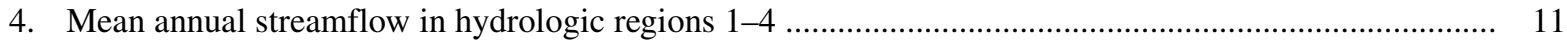

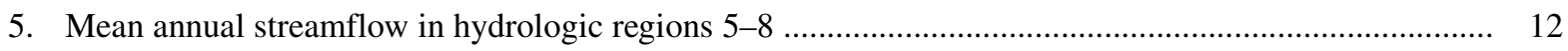

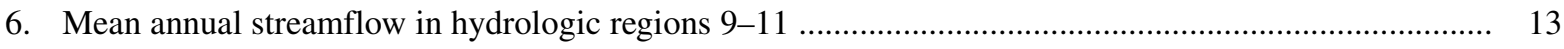

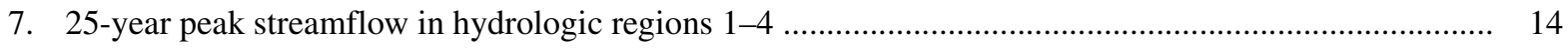

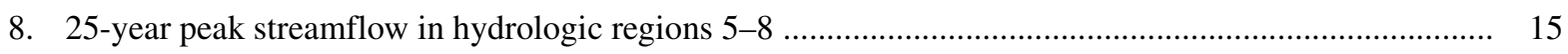

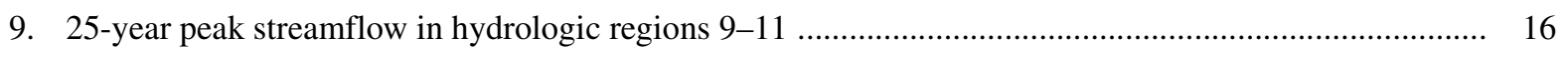

10-11. Maps showing correlation of annual mean streamflow between paired streamflow-gaging stations in:

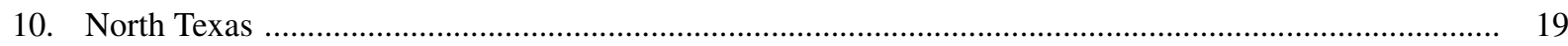

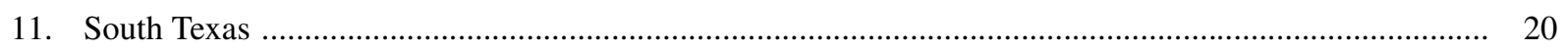

12-13. Maps showing correlation of annual peak streamflow between paired streamflow-gaging stations in:

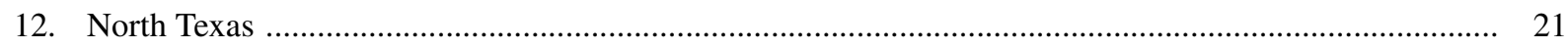

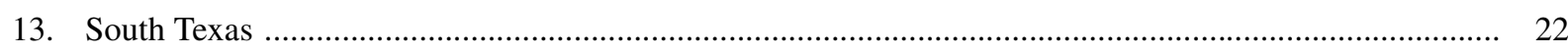




\section{TABLES}

1. Correlation coefficients of annual mean streamflows for paired stations in north Texas basins

2. Correlation coefficients of annual mean streamflows for paired stations in south Texas basins

3. Correlation coefficients of annual peak streamflows for paired stations in north Texas basins

4. Correlation coefficients of annual peak streamflows for paired stations in south Texas basins

5. Core network of streamflow-gaging stations in Texas 


\title{
Evaluation of the Streamflow-Gaging Network of Texas and a Proposed Core Network
}

\author{
By Raymond M. Slade, Jr., Teresa Howard, and Roberto Anaya
}

\section{Abstract}

The U.S. Geological Survey streamflowgaging network in Texas is operated as part of the National Streamgaging Program and is jointly funded by the Geological Survey and Federal, State, and local agencies. This report documents an evaluation of the existing (as of October 1, 1999) network with regard to four major objectives of streamflow data; and on the basis of that evaluation, proposes a core network of streamflowgaging stations that best meets those objectives. The objectives are (1) regionalization (estimate flows or flow characteristics at ungaged sites in 11 hydrologically similar regions), (2) major flow (obtain flow rates and volumes in large streams), (3) outflow from the State (account for streamflow leaving the State), and (4) streamflow conditions assessment (assess current conditions with regard to long-term data, and define temporal trends in flow). The network analysis resulted in a proposed core network of 263 stations. Of those 263 stations, 43 were discontinued as of October 1, 1999, and 15 were partial-record stations. Fifty-five of the proposed core-network stations meet two of the four major objectives, 16 stations meet three objectives, and 1 station meets all four. One-hundred eighty-five stations with a median record length of 33 years were selected to meet the regionalization objective. Ninety-two stations with a median record length of about 62 years were selected to meet the major-flow objective. Twenty-six stations with a median record length of 59 years were selected to meet the outflow from the State objective. Fifty stations with a median record length of 53 years were selected to meet the streamflow conditions assessment objective.

\section{INTRODUCTION}

\section{Background}

The Texas District of the U.S. Geological Survey (USGS), currently (1999) operates more than 300 streamflow-gaging stations in Texas. The stations, which fulfill multiple data needs, are operated with funding cooperation from Federal, State, and local governmental agencies and are part of the USGS National Streamgaging Program (described at http://water.usgs. gov/osw/programs/streamgaging.html). The Texas Water Development Board (TWDB) is the cooperating agency for the most stations. More than 25 years ago the USGS proposed a core streamflow-data network for Texas (Gilbert and Hawkinson, 1971). Data uses and funding were analyzed in 1985 (Massey, 1985). Since the original core network was proposed, the number of active streamflow-gaging stations has declined. As the State population and water use increase, the importance of a core streamflow-gaging network to provide surface-water information and to monitor water resources, especially during floods or droughts, increases.

The USGS operates two basic types of streamflow stations: continuous-record stations and partialrecord stations. Continuous-record stations include daily flow stations for which instantaneous and daily mean streamflow are computed, and stage-only stations for which daily mean water levels are computed. Daily mean streamflows for the daily flow stations and daily mean water levels for the stage-only stations are published annually by the USGS.

Partial-record stations include flood-hydrograph stations for which daily mean streamflows that exceed a specific base discharge are computed; crest-stage stations for which annual peak streamflows are computed from peak stage data; and low-flow stations where streamflows are measured periodically. Daily mean and 
annual peak streamflows are published annually by the USGS; those data, along with recent instantaneous streamflows, are available at the USGS Texas home page at http://tx.usgs.gov/.

\section{Purpose and Scope}

The purpose of this report is to evaluate the existing ${ }^{1}$ streamflow-gaging network of Texas with regard to four major objectives, and on the basis of that evaluation, propose changes to the existing network to better accomplish those objectives. Implementing the proposed changes to the streamflow-gaging network will result in a core network-a system of streamflowgaging stations required to accomplish the four major objectives of the USGS and the TWDB. Streamflowgaging stations on the Rio Grande and some of its larger tributaries that are operated by the International Boundary and Water Commission (IBWC) were not included in this analysis. Stations that gage springflow or flow in canals also were excluded; thus the gaging stations in this report represent streamflow from specific basins.

\section{STREAMFLOW NETWORK ANALYSIS}

\section{History of Streamflow Gaging in Texas}

The first streamflow-gaging station to record daily mean streamflow in Texas began operation in 1889. The station, located on the Rio Grande near El Paso, collected data in support of the design and operation of Elephant Butte Dam (Texas Board of Water Engineers, 1960). Several short-term stations collected streamflow data from major streams between 1895 and 1914 (Gilbert and Hawkinson, 1971). Systematic data collection commenced in 1897 with the establishment of four additional long-term stations (Massey, 1985). Daily flow stations still in operation today were installed on the Colorado River at Austin and on the Brazos River at Waco in 1898. By the beginning of the 20th century, the American Section of the IBWC began to collect streamflow data along the Rio Grande in Texas.

In 1915, the USGS and the State of Texas initiated formal cooperation in a statewide program to collect water-resources data, and the number of Texas stations more than doubled (fig. 1). Extensive flooding in 1921 created the impetus for rapid expansion of the gaging

${ }^{1}$ In this report, existing means as of October 1, 1999. network. By 1925, more than 100 gaging stations were active, and 36 of the stations were equipped with data recorders. After 1925, however, network expansion ceased for about a decade because of a lack of cooperative funding. After Texas experienced catastrophic floods nearly every year from 1932 to1939, and with the passage of the Flood Control Act of 1936, the U.S. Army Corp of Engineers (USACE) funded 55 new stations. By 1939, the Texas streamflow-gaging network began to expand and remained stable during World War II.

From 1940 to 1951, most stations were installed as support for water-resources development (Gilbert and Hawkinson, 1971). In 1952, an investigation of the effect of U.S. Soil Conservation Service floodprevention projects led to the installation of stations on streams with rural drainage areas of less than 250 square miles. The former Texas Board of Water Engineers (TBWE) (now Texas Water Development Board) reported that more than 220 continuous record streamflow-gaging stations were in operation in the State on September 30, 1957. During the decade from 1958 to 1968, the USGS established many more stations in Texas.

As data collection increased and quantitative methods were developed for engineering projects, the State Highway Department (now Texas Department of Transportation) identified the need for data pertinent to the magnitude and frequency of flood stage and discharge for use in bridge and culvert design (Massey, 1985). From 1964 to 1974, a statewide network of about 150 flood-hydrograph and crest-stage partialrecord stations gathered considerable data that defined the characteristics of peak flows from small rural drainage areas. On the basis of these data, Schroeder and Massey (1977) developed equations to estimate peakstreamflow frequency for natural basins in Texas. Eighteen years later, Asquith and Slade (1995) analyzed the existing peak-streamflow database and reported on the maximum documented peak streamflow for stations and other sites throughout Texas. Two years later, the database was used to develop equations to estimate peak-streamflow frequency for natural basins in Texas (Asquith and Slade, 1997). The database also was used to define equations to estimate long-term mean streamflow for natural basins in Texas (Lanning-Rush, 2000).

The streamflow-gaging network peaked in 1972 with the operation of about 650 stations (fig. 1). From 1972 to 1996 , the number of daily flow stations decreased from about 420 to less than 300 . The gradual 


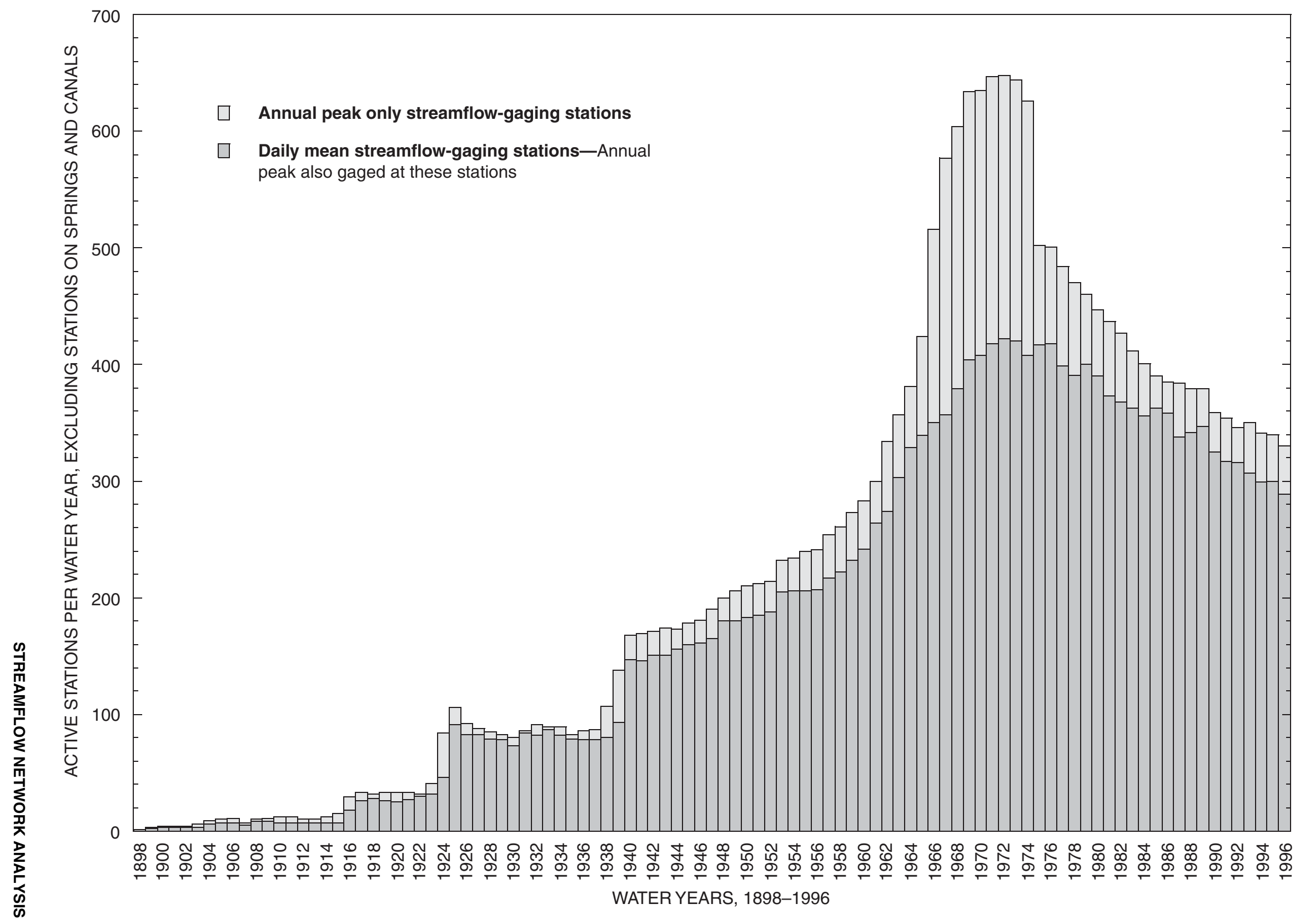

$\omega \quad$ Figure 1. Number of daily mean and annual peak streamflow stations in Texas, 1898-1996. 


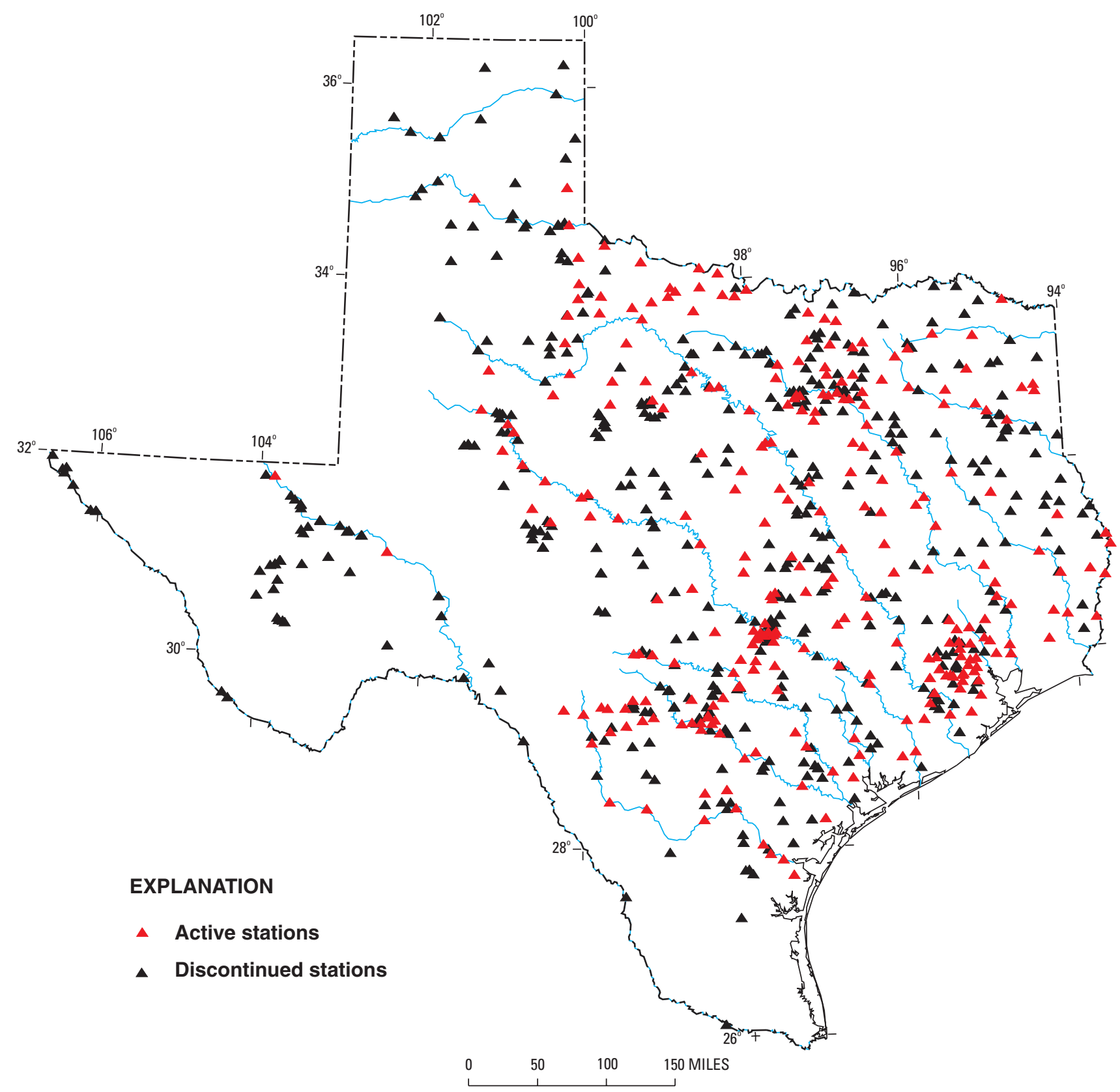

Figure 2. Locations of active and discontinued daily streamflow stations, October 1, 1998.

decline of the streamflow-gaging network has continued to the present time (1999). On October 1, 1998, the USGS streamflow-gaging network in Texas consisted of 312 daily flow stations (including springs and canals), 17 stage-only stations, 58 floodhydrograph stations, 27 crest-stage stations, and 25 lowflow stations. The locations of all active and discontinued daily flow stations as of October 1, 1998, are shown in figure 2.

\section{Network Evaluations in Texas}

In Texas, three previous reports assess the State's streamflow-gaging network. In 1960, the TBWE published a report in cooperation with the USGS that evaluated the existing streamflow-gaging network and made recommendations for its expansion (Texas Board of Water Engineers, 1960). The report concluded that streamflow-gaging stations had been established in 
response to the data requirements of individual Federal and State agencies and local entities; and that a more systematic approach would improve understanding of hydrologic conditions in the State's widely variable watersheds. Citing the fact that physiographic and climatic diversity precluded the use of streamflow data from one basin to accurately predict streamflow in another, the TBWE proposed the establishment and maintenance of a network in accordance with USGS policy and philosophy. Specifically, two general classifications of streamflow-gaging stations were defined: hydrologic-network stations that provide data from natural, unregulated basins that could be used both for planning and design of future water-development projects and in research seeking scientific solutions to hydrologic problems; and watermanagement stations designed to meet specific data needs and to provide information about present and past streamflow conditions.

The TBWE analysis identified 88 stations from the 296 streamflow- and stage-recording stations in September 1958, as areal primary stations satisfying the conditions of regional representation and length of record necessary for hydrologic investigations; and proposed the reactivation or establishment of 58 additional areal stations for the primary network, for a total of 146 areal primary stations. Thirty-two stations were identified as areal secondary stations, and the study recommended the addition of 131 stations in the areal secondary category, for a total of 163 areal secondary stations. The goal of areal secondary stations was to collect sufficient data to correlate streamflow with that at areal primary sites. The TBWE report stated that 5 to 10 years of streamflow record collected at a secondary station usually would define an adequate correlation.

A decade later, Gilbert and Hawkinson (1971) presented the results of their analysis of the 1970 Texas streamflow-gaging network of 464 stations as part of a national evaluation program. They concluded that the most serious deficiency in the collection of natural streamflow data was in the western one-third of the State, and accordingly, proposed the addition of nine stations in that region. They found the network in the eastern two-thirds of the State to be adequate. They further concluded that data collection from regulated streams was deficient and suggested additional gaging of inflow to and (or) outflow from 20 reservoirs.

Massey (1985) analyzed data uses and funding for the USGS streamflow-gaging stations in Texas, as part of a project to determine cost-effectiveness of the
State's data program. The study presented a table of data use, station funding, and data availability for 391 continuous-record streamflow-gaging stations. The report concluded that all stations active in 1984 have sufficient uses to justify their continued operation. The three network-funding and nine data-use categories as defined in the report are presented in the following section.

\section{NETWORK FUNDING AND DATA USES}

The three sources of funding for the streamflowdata program are:

1. Federal program-funds directly allocated to the USGS for the purpose of collecting streamflow data.

2. Other Federal Agency (OFA) program - funds that have been transferred to the USGS by other Federal agencies for data collection by the USGS to meet the needs of those agencies.

3. Federal-State Cooperative programs-funds that combine USGS cooperative-designated Federal funding and funding from a non-Federal cooperating agency. Cooperating agency funds can be in the form of cash or direct services.

Each station in the streamflow-gaging network can be classified into one or more of the nine data-use categories defined by Massey (1985). The definitions of the nine primary data uses and the classification of stations active on October 1, 1999, are as follows:

Regional Hydrology: The relations between streamflow characteristics (measures of mean flows, peak flows, and low flows) and basin characteristics (geography and climate) form the basis of regional hydrology. The relation between streamflow and factors such as drainage area and precipitation characteristics can be used to estimate streamflow characteristics at ungaged sites. However, data must be gathered from streams largely unaffected by impoundments or diversions so that empirical relations are meaningful.

In the Texas network, six existing stations were in the regional hydrology data-use category. Two of the stations were designated as benchmark stations and four were index stations. Benchmark stations are part of the Hydrologic Benchmark Network of 50 sites nationwide in small drainage basins that are relatively free from human alterations. Data collected at benchmark stations provide information about the changing quantity and 
quality of streamflow and other conditions related to long-term trends. Index stations are long-term stations used to prepare a national monthly summary of water conditions.

Hydrologic Systems: Hydrologic-system stations provide data used to define current hydrologic conditions and to monitor changes and trends in the movement of water in both unregulated and regulated systems. Stations recording diversions and return flows and the passage of flows through regulated storage systems as well as stations defining the interaction of water systems are in this category.

Almost 95 percent of existing daily flow stations were hydrologic-systems stations. The Texas Natural Resource Conservation Commission (TNRCC) relies on data from many of these stations to administer wateruse permits throughout the State. Various river authorities also use hydrologic-system stations to allocate water resources among users.

Legal Obligations: The USGS sometimes is obligated to operate stations to satisfy certain legal requirements, which include the verification or enforcement of existing treaties, compacts, and decrees. As of October 1,1999 , no stations in the Texas program were in this category.

Planning and Design: Certain projects require streamflow record for proper design and planning. Such projects include the construction or operation of dams, bridges, floodwalls, water-supply diversions, hydropower plants, and wastewater-treatment facilities. Stations in the planning and design data-use category were installed specifically for such projects and continue to serve in this capacity.

About 60 of the existing daily flow stations in Texas were in the planning and design data-use category. Among the cooperators for this type of station are the TNRCC, USACE, municipalities, and several river authorities.

Project Operation: These stations assist water managers in making operational decisions affecting reservoir releases, hydropower operations, or diversions for irrigation and other water consumption. To be useful for project operation, data must be available to operators on a real-time or near real-time basis. Routine data availability every few days might be sufficient for some projects on large streams.

About 100 of the existing daily flow stations were in the project-operation category. Data users include the
TNRCC, TWDB, various river authorities, municipal water districts, flood control districts, USACE, and Bureau of Reclamation.

Hydrologic Forecasts: Accurate hydrologic forecasting relies on dependable and accurate near real-time data. Hydrologic-forecast gaging stations form the basis for flood forecasts in specific river reaches and for periodic flow-volume forecasts at specific locations or in regions at daily, weekly, monthly, or seasonal intervals. Another use of stations in this category is for the monitoring of low-flow conditions during times of drought. Stations in this category generally provide data on a real-time, or near real-time basis.

Stations designated by the National Weather Service as necessary for flood forecasting are in the hydrologic-forecast category. Other agencies including the TWDB, TNRCC, river authorities, municipal water districts, and USACE might use data during flood and drought conditions. Most streamflow data in Texas are available on a near real-time basis. Data are available to cooperators and the general public on the Internet.

Because of rapid data transmission and data accessibility, nearly all existing streamflow-gaging stations were in the hydrologic-forecast data-use category.

Water-Quality Monitoring: Streamflow data at gaging stations where water-quality or sediment-transport data are collected are essential to the interpretation of chemical and biological constituents, sediment concentrations, and computation of daily and annual loads. About 180 streamflow-gaging stations operated by the USGS with funding from many cooperators were in this category. Stations in urban areas collect data related to the effects of urban runoff. Other stations monitor discharges from sewage-treatment facilities and industrial plants. Some stations provide data to help define eutrophication and turbidity problems in water supplies.

Stations operated as part of the National StreamQuality Accounting Network (NASQAN) also are included in this category. NASQAN stations measure the amount of chemicals and sediment in flow at sites on the Nation's largest rivers to characterize sub-basins, identify regional source areas of chemicals and sediment, and assess human influences on observed concentrations and amounts of these materials. In the past, about 40 NASQAN stations were operated in Texas; as of October 1, 1999, only 8 NASQAN stations were active -7 on the Rio Grande and 1 on a tributary to the Rio Grande. The USGS monitors water quality at the 
NASQAN stations, and the IBWC is responsible for streamflow-gaging operations at these stations.

Research: Gaging stations operated for research or water-investigations studies typically are in place for a limited time, often for only a few years. In the past, such stations have collected streamflow data to support model development.

About 80 existing stations were in the research category. About 30 of the stations are part of an urban hydrology project in Houston, and another 27 stations are part of a project to identify nonpoint discharge sources in urban areas. Eight investigations throughout the State used the remaining stations in the research data-use category.

Other: Streamflow-gaging stations in at least one of the eight categories also provide useful information for recreational planning. Canoeists, rafters, and fishermen who enjoy the streams of Texas benefit from the public availability of data from USGS gaging-stations. No stations, however, are operated or funded primarily for recreational purposes. The "other" category reflects the fact that streamflow data can be useful for purposes other than the original purpose of the station.

\section{MAJOR OBJECTIVES OF A CORE NETWORK}

The USGS and the TWDB defined four major objectives of a core network of streamflow-gaging stations for Texas. A gaging station must provide data that contribute to at least one of the four objectives to justify its inclusion in the core network. The four objectives are:

1. Regionalization (estimate flows or flow characteristics at ungaged sites in 11 hydrologically similar regions).

2. Major flow (obtain flow rates and volumes in large streams).

3. Outflow from the State (account for streamflow leaving the State).

4. Streamflow condition assessment (assess current conditions with regard to long-term data and define temporal trends).

The specific number of stations to be included in the network was not predetermined. All active and discontinued stations were considered for inclusion in the core network. New stations were not considered because the large network of active and discontinued stations was assumed to be a sufficient pool of stations from which to select the core network. Also, the historical data needed for each station in the core network are not available for new stations. Because of the expense involved in reactivating stations, a discontinued station was included in the core network only if it made a substantial contribution. Existing stations not included in the core network provide redundant data, data for specific studies, or data needed to meet other objectives. The USGS might continue to support and operate such stations but not as part of the core network. The remainder of this section describes the purpose for each objective and the defining factors used to select stations that meet the criteria of each objective.

Regionalization: It is not economically feasible to gage every stream site of interest. Thus other means are necessary to estimate flows or flow characteristics at ungaged sites. Regionalization stations must be located in natural, or mostly natural, basins and provide data important for defining flow characteristics in regions with similar hydrologic characteristics (fig. 3). Stations are distributed within each hydrologic region to characterize the range of basin characteristics (drainage area, main channel slope, and basin shape) of each region. Regionalization stations commonly are used to estimate low-, mean-, and high-flow characteristics at ungaged sites. Stations meeting the criteria for this objective provide data to develop regional regression equations for estimating flow characteristics and for simulation of flows or flow characteristics at specific ungaged sites. The USGS and other agencies maintain computer programs to estimate streamflow and streamflow characteristics for ungaged sites. Such computer programs and statistical procedures typically require data from gaged sites for model calibration.

Major Flow: The second objective of the core network is to monitor and define streamflow rates and volumes from major streams in the State. Stations monitoring major flows provide information crucial for waterresource management and thus are important to the TWDB, TNRCC, and other agencies. The major streams of Texas (pl. 1) provide the largest flow volumes and much of the State's water supply. Decisions concerning water allocation for municipalities, agriculture, and industry (particularly in times of drought) depend on timely information about major flows.

For the purpose of this objective, a major flow is defined as the streamflow from a contributing drainage 


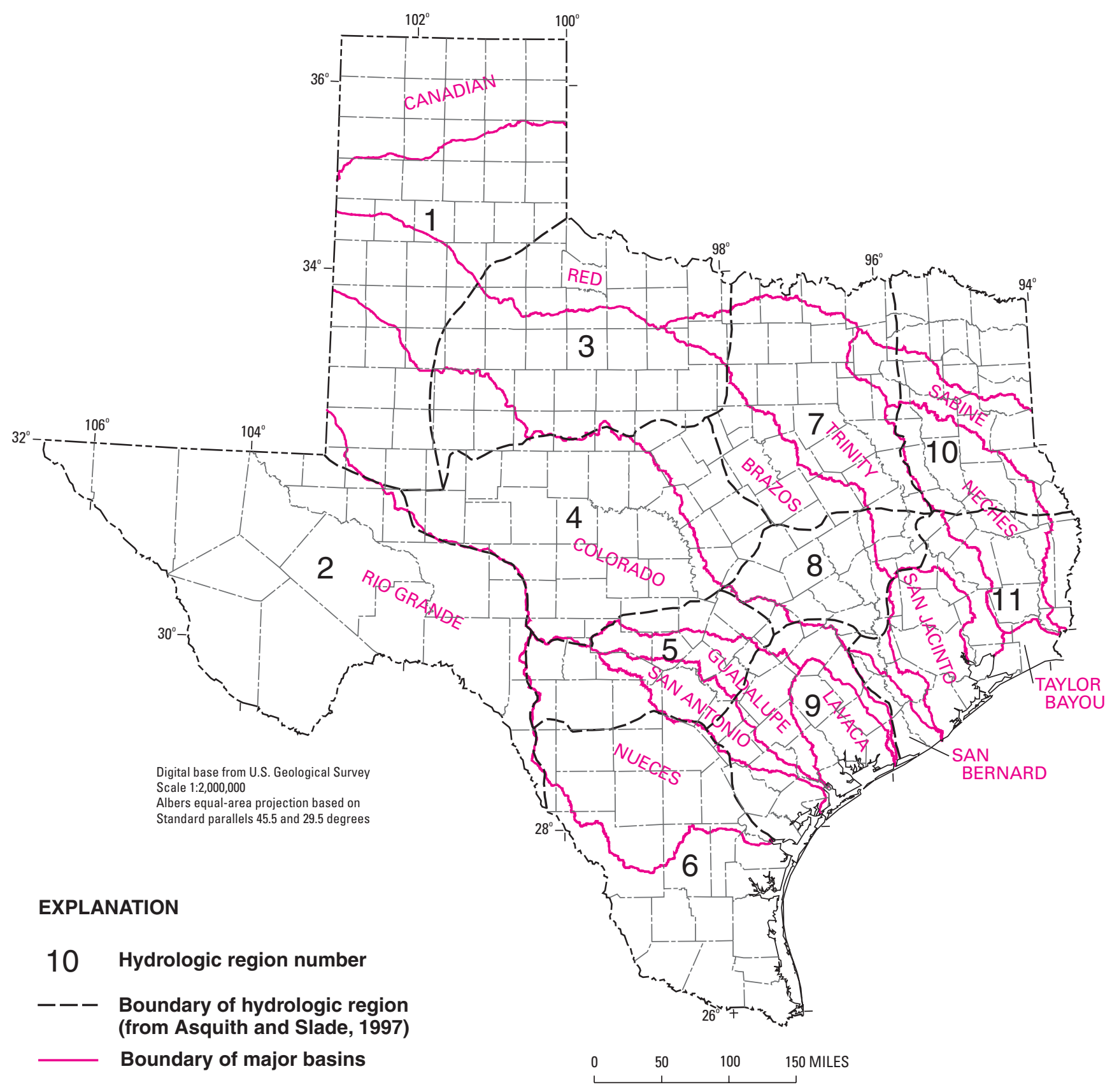

Figure 3. Hydrologic regions and major basins of Texas.

area of at least 1,000 square miles or as the streamflow of a river whose base flow is sustained by major springs. The Comal River (springflow from Comal Springs) and San Marcos River (springflow from San Marcos Springs) are the two streams in the State in the latter category. Most major flows in the State are regulated, so stations on these streams typically are not suitable for predicting flows or flow characteristics at other sites.
However, data from these stations are needed for waterresource management. A sufficient number of stations on each major stream is required to define changes in streamflow over time and space. Many existing stations were excluded from the core network because their streamflow data are made redundant by nearby stations on the same stream. An analysis of the streamflow correlation between stations is presented later in this report. 
Outflow from the State: The third major objective of the core network is to account for outflow from the State. Stations that provide data to meet this objective are at sites along the Gulf of Mexico or on the eastern border of the State and gage flow from basins greater than about 1,000 square miles. Their data define the quantity (and quality) of water leaving the State and can be used, along with data from stations gaging inflow to the State, to document statewide or basinwide water budgets of runoff. The effects of changes in land use, stream impoundment, and withdrawal rates are represented in the data collected at State outflow sites. Periodic water-quality and suspended-sediment data have been collected at most outflow stations. Such data, in combination with streamflow data, provide estimates of water-quality-constituent loads and trends in water-quality-constituent loads of flow into the Gulf of Mexico. Previous studies (Slade, 1992; Judd, 1995) have investigated streamflow to the Gulf of Mexico and include data from stations in Texas located near the Gulf of Mexico.

Most of the major basins in Texas originate within the State. Streamflow from the Canadian River, Pecos River, and Rio Grande, however, originates in New Mexico. A stream station on the Canadian River in New Mexico (Canadian River at Logan, N. Mex.) monitors inflow to Texas from that stream, a station on the Pecos River in Texas (Pecos River near Orla, Tex.) monitors inflow to Texas from that stream, and a station on the Rio Grande in Texas (Rio Grande at El Paso) monitors inflow to Texas from that stream.

Streamflow Conditions Assessment: Stations that provide data to meet the objective of streamflow conditions assessment must be long-term, geographically diverse stations with large natural, or mostly natural, basins. Data from these stations are used for assessment of flow conditions throughout the State and for analyses of temporal trends in streamflow. To be included in this category, a station must have at least 15 years of daily streamflow record; most of the stations have at least 30 years of record. Stations that provide data to meet the assessment objective must be distributed throughout the State so that the different hydrologic regions are represented. Streamflow-conditionsassessment stations provide information for both shortterm and long-term planning. Stations that provide data to meet this objective also serve as indicators of both drought and flood conditions.

\section{EVALUATION OF THE EXISTING NETWORK}

Several tools were either developed or applied in the evaluation to determine whether stations should be included in the core network. Simple definition tests were sufficient to identify stations that met the criteria for three of the objectives: major flow, outflow from the State, and streamflow conditions assessment. Two tools were used to determine whether stations met the criteria for the regionalization objective: boundaries of hydrologic regions and a regional optimization model. A third tool, flow correlation analysis, was used to identify stations that provide redundant flow data, in order to minimize the number of stations needed to form the core network.

\section{Hydrologic Regions}

To conduct regional analysis of streamflow characteristics, the State was subdivided into regions that have relatively homogeneous hydrologic characteristics. The USGS has identified hydrologic regions (fig. 3) to define areas of similar climatology (precipitation and evaporation), physiography, surface geology, soils, and vegetation in previous studies (Asquith and Slade, 1995, 1997).

Delineation of the hydrologic regions was based primarily on reports by Carr (1967) and Kier and others (1977). Delineation also was influenced by drainagebasin boundaries for the major streams and areal density of the existing streamflow-gaging stations. Majorstream drainage-basin boundaries in Texas generally are oriented from northwest to southeast, and many of the hydrologic boundaries are aligned with those drainage boundaries. Climatic-division boundaries, however, along with physiographic and geologic boundaries, generally are aligned perpendicular to the basin boundaries. The hydrologic boundaries that are oriented perpendicular to major-stream basin boundaries are closely aligned with climatic, physiographic, and geologic boundaries. Also, an effort was made to pass hydrologic boundaries through areas with few streamflow-gaging stations. Where feasible, the boundaries were located downstream from areas of relatively dense station distribution, so that stations would be in the same regions as their drainage basins. Eleven hydrologic regions formed the basis of the regional optimization model. 


\section{Regional Optimization Model}

The objective of the regional optimization model (Tasker and Stedinger, 1989) is to develop an effective gaging strategy to indicate where gaging stations should be located and how long they should be operated to maximize hydrologic information that could be used for regional analyses. This model was used to identify the stations for the regionalization objective. To optimize regional hydrologic information subject to a set of budget constraints, a backward-step regression technique was used to identify the relative value of data for all active and discontinued gaging stations. On the basis of the relative value of a stations's data, along with the cost to operate existing stations and the cost to install and operate discontinued stations, the regionalization gaging network can be optimized on the basis of data value and expense. In addition to the budget constraints, stations that must remain active in the future were identified in the model. The model is based on regionalizing mean annual flows and 25-year peak discharges from basin characteristics such as drainage area, basin slope, basin shape, and mean annual precipitation (Tasker and Stedinger, 1989).

The regional regression method that relates mean annual flow or 25-year peak discharge at a station to drainage-basin characteristics is a multivariable regression model that can be written, after suitable transformations, in the form of the following linear equation:

$$
\mathrm{Y}=\mathrm{X} \beta+\varepsilon,
$$

where

$$
\begin{aligned}
\mathrm{Y}= & \text { logarithms of mean annual flows or } 25 \text {-year } \\
& \text { peak discharges at all stations within a region, } \\
\mathrm{X}= & \text { basin characteristics for the region, } \\
\beta= & \text { regression parameters to be estimated, and } \\
\varepsilon= & \text { random errors for the model. }
\end{aligned}
$$

The mean annual flows and the 25-year peak discharges were log-transformed to achieve a more linear relation. Stedinger and Tasker (1985) and Tasker and Stedinger (1989) provide details for estimating $\beta$ and $\varepsilon$ using general least-squares (GLS) regression methods.

In general, GLS regression methods maximize regional hydrologic information by minimizing the average of the mean square error of prediction (MSEP) over a representative set of basin characteristics for all stations within a region. The MSEP, also known as the mean error variance, is a combination of the inherent model error variance (MEV) and the sampling error variance (SEV) for a station. The MEV remains constant for each region; therefore the average MSEP for each region is a function of the average sampling error variance (ASEV) constrained by a budget. The ASEV can be reduced by collecting new data, either by activating discontinued stations and adding them to the regression, by operating stations for longer periods, or by a combination of these two methods. This property of the ASEV allows an evaluation of the effects of collecting new data using different gaging strategies on the predictive ability of regional regression models and forms the basis for the network analysis that follows.

The ASEV can be computed from MSEP as a function of budget constraints such as the number of stations being operated and the length of the period of operation, referred to hereafter as a planning horizon. Fundamentally, the computation poses a very large nonlinear integer programming problem; however, an approximate solution can be obtained using a backward-step approach.

In summary, the backward-step approach begins with the computation of the ASEV for all possible gaging stations within a region being operated for a specified planning horizon. In an iterative process, a single gaging station then is dropped and the ASEV recomputed such as to maintain the minimum ASEV. This iterative process is continued until the minimum budget is achieved. The ASEV values are then transformed into mean sampling errors (in percent). This approach is applied separately for mean annual flows and 25-year peak discharges for each of 5-, 10-, and 20year planning horizons and for each of the 11 hydrologic regions in Texas.

Figures 4-6 show the results from the model for the three planning horizons for the mean annual streamflows; every active and discontinued station with daily streamflow data in a natural basin was included in the model (352 stations). Figures 7-9 show the results for the same planning horizons for the 25 -year peak discharges; 519 stations (all stations with annual peak data in a natural basin) were included in the model. The budget constraints are expressed in terms of the number of stations operated during the indicated planning horizons. The three curves in each figure show that, as the gaging stations are operated for longer periods of time, the mean sampling error is reduced. The shape of the curves indicates that, as more stations are kept active, the mean sampling error is reduced to a minimum, beyond which increasing the number of stations operated does not decrease mean sampling error. 

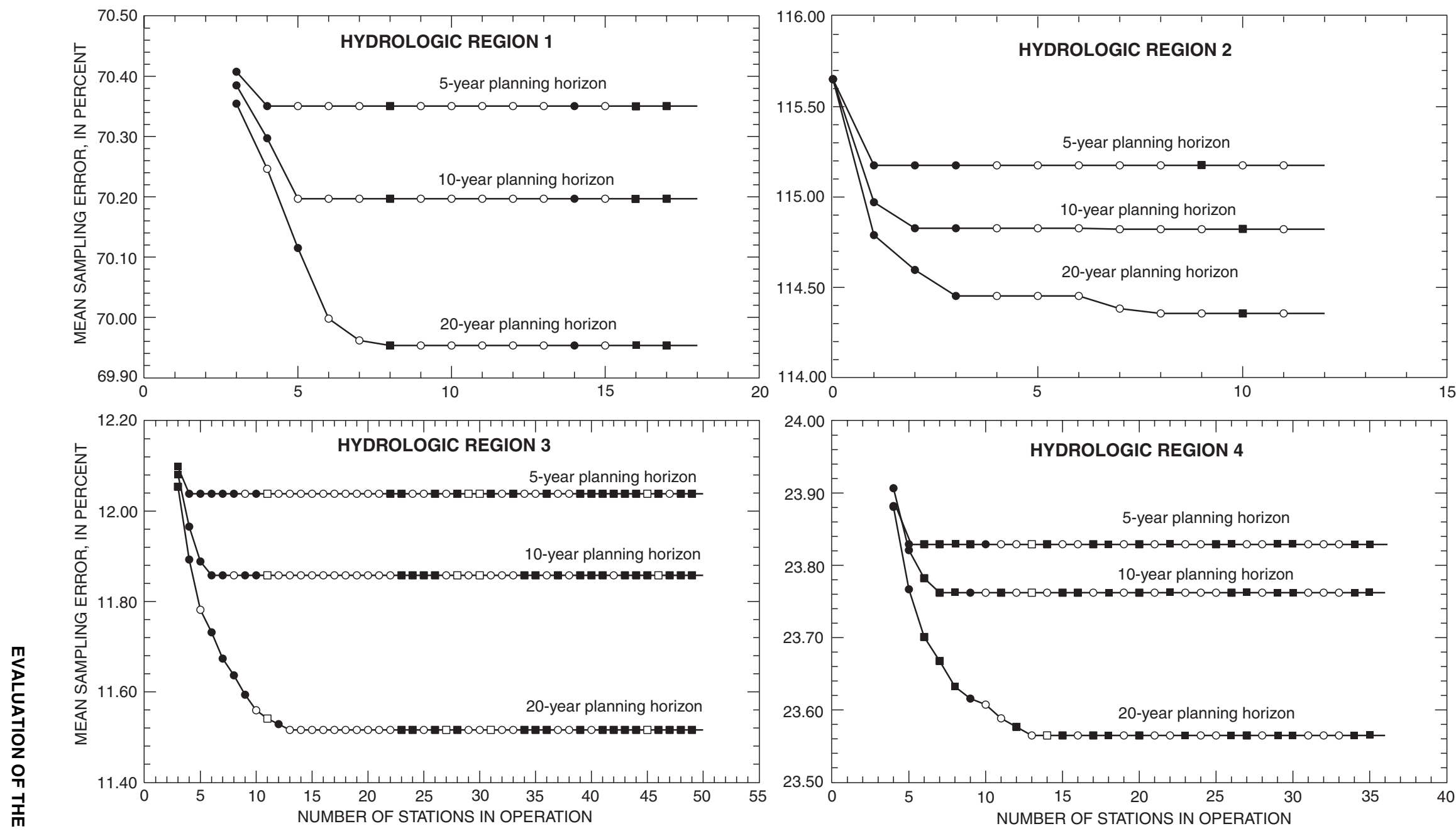

\section{EXPLANATION}

- Discontinued station selected for core network

- Discontinued station not selected for core network
- Active station selected for core network

口 Active station not selected for core network

Figure 4. Relation between mean sampling error, number of streamflow-gaging stations, and planning horizon for mean annual streamflow in hydrologic regions $1-4$. 

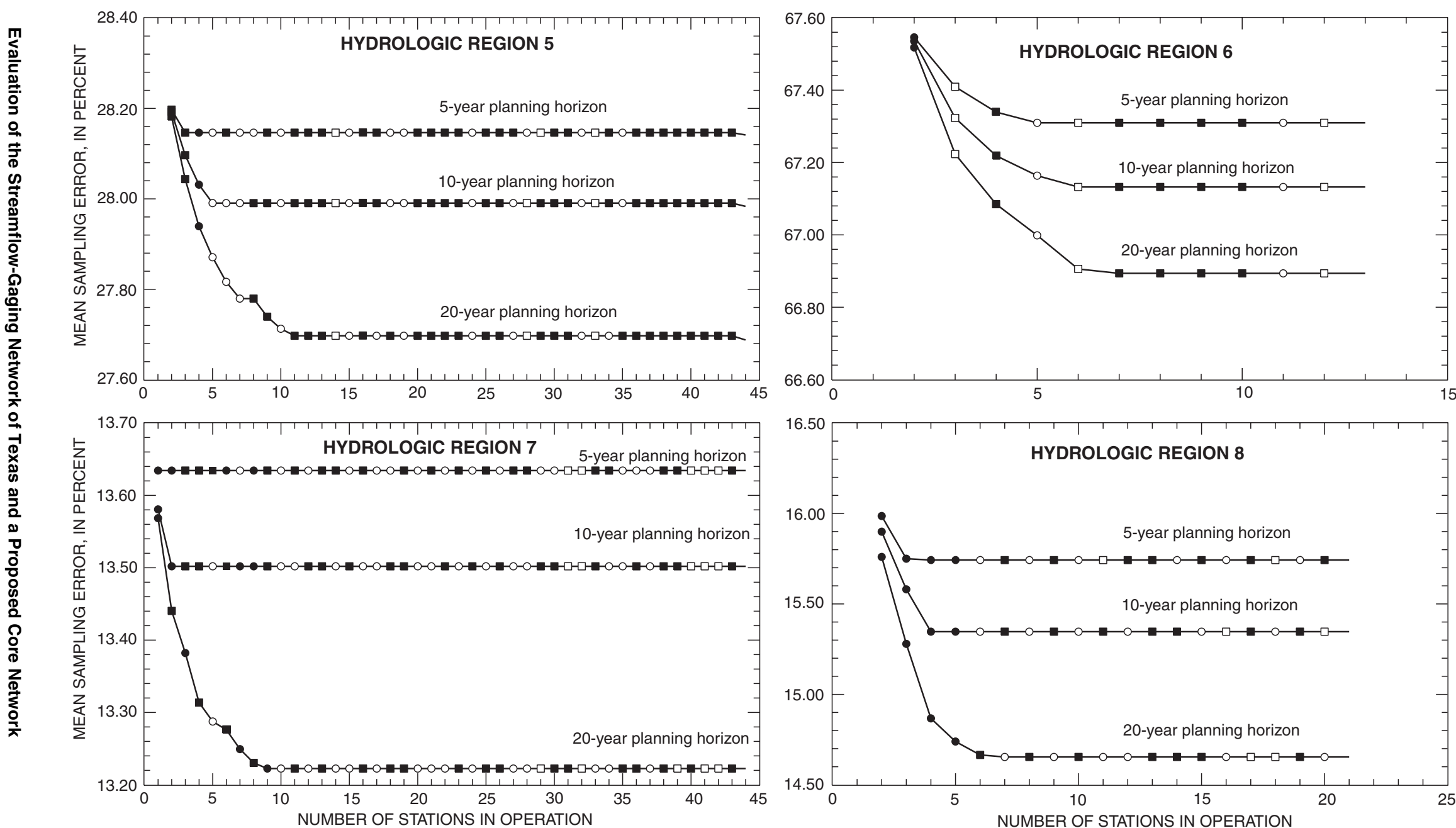

\section{EXPLANATION}

- Discontinued station selected for core network

- Active station selected for core network

- Discontinued station not selected $\square$ Active station not selected for core network for core network

Figure 5. Relation between mean sampling error, number of streamflow-gaging stations, and planning horizon for mean annual streamflow in hydrologic regions $5-8$. 

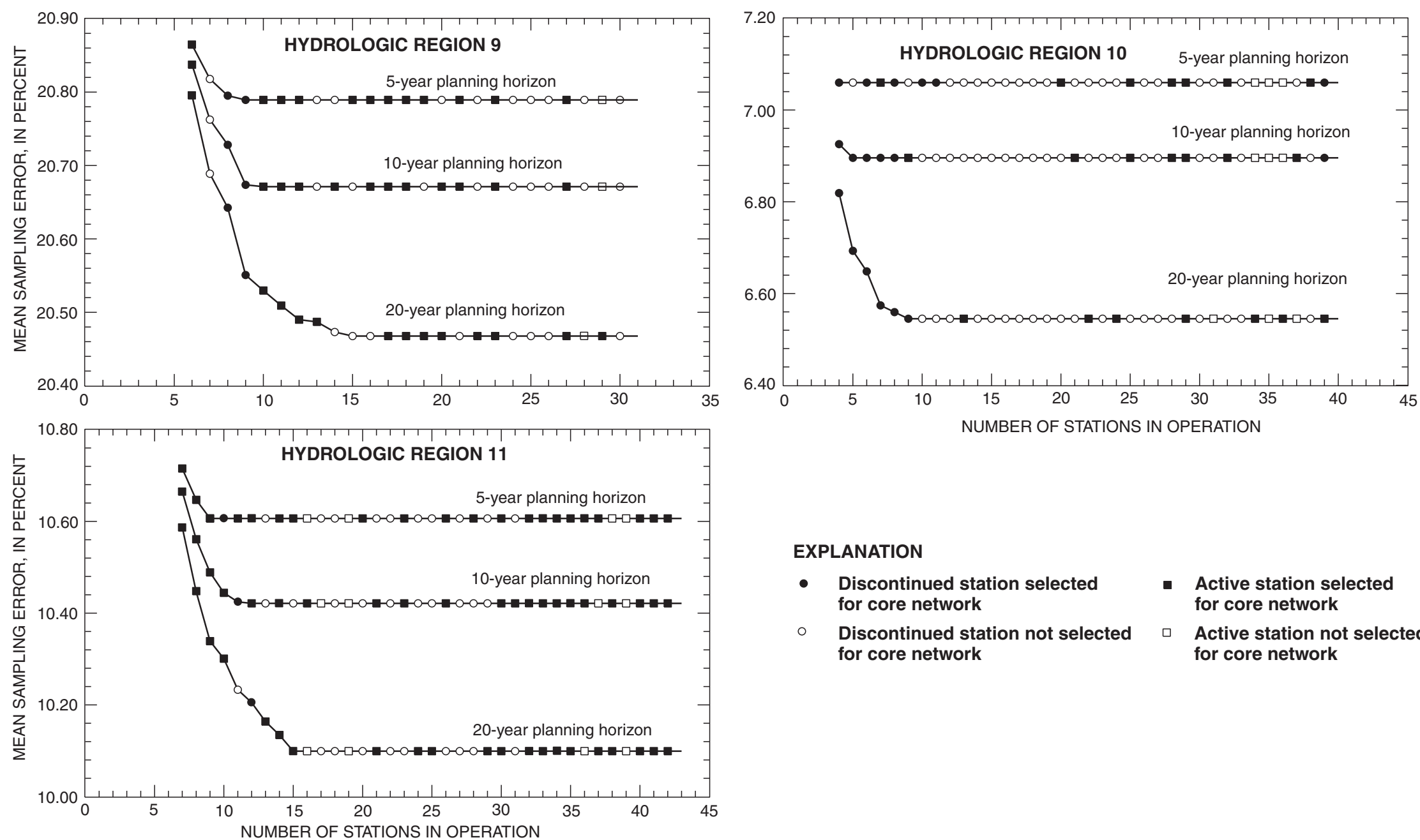

\section{EXPLANATION}

- Discontinued station selected for core network

- Discontinued station not selected for core network
- Active station selected for core network

Active station not selected for core network

Figure 6. Relation between mean sampling error, number of streamflow-gaging stations, and planning horizon for mean annual streamflow in hydrologic regions 9-11. 

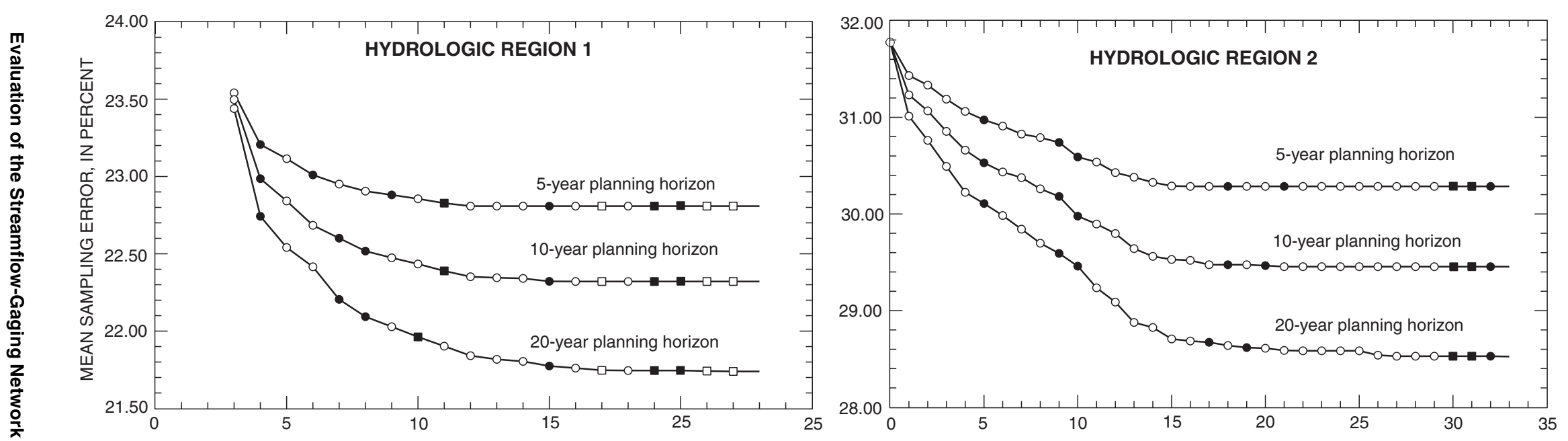

0
0
0
0
0
0
0
0
0
0
0
0
0
0
0
0
0
0
0
0
0
0
0
0
0
$\vdots$
0
0
$\frac{1}{x}$
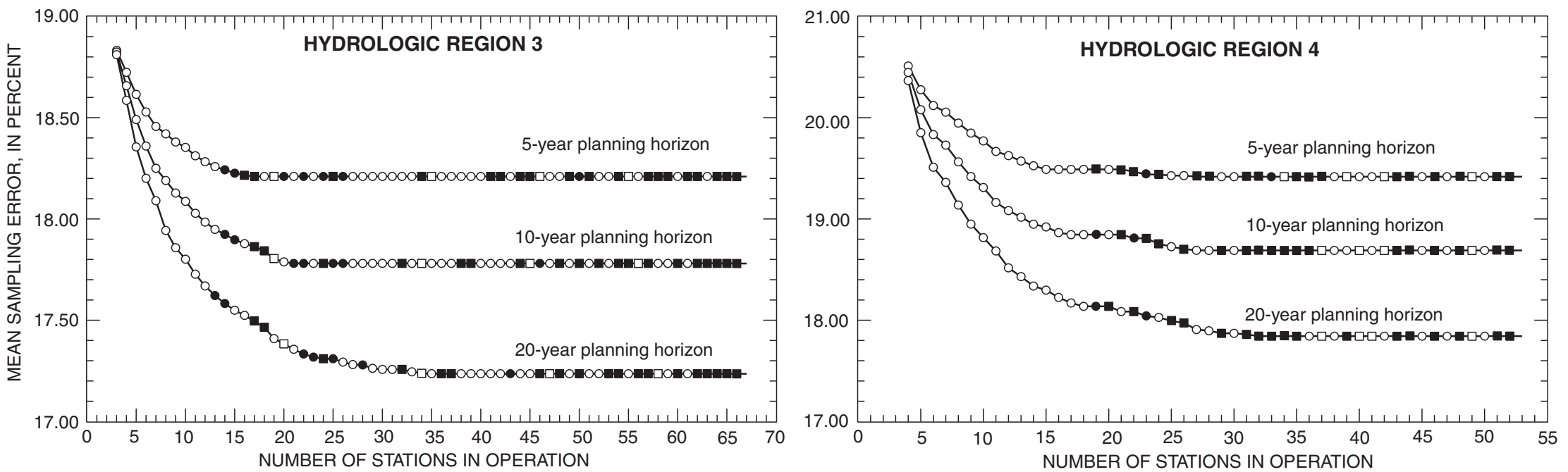

\section{EXPLANATION}

- Discontinued station selected for core network

- Active station selected for core network

- Discontinued station not selected $\quad \square \quad$ Active station not selected for core network for core network

Figure 7. Relation between mean sampling error, number of streamflow-gaging stations, and planning horizon for 25-year peak streamflow in hydrologic regions $1-4$. 

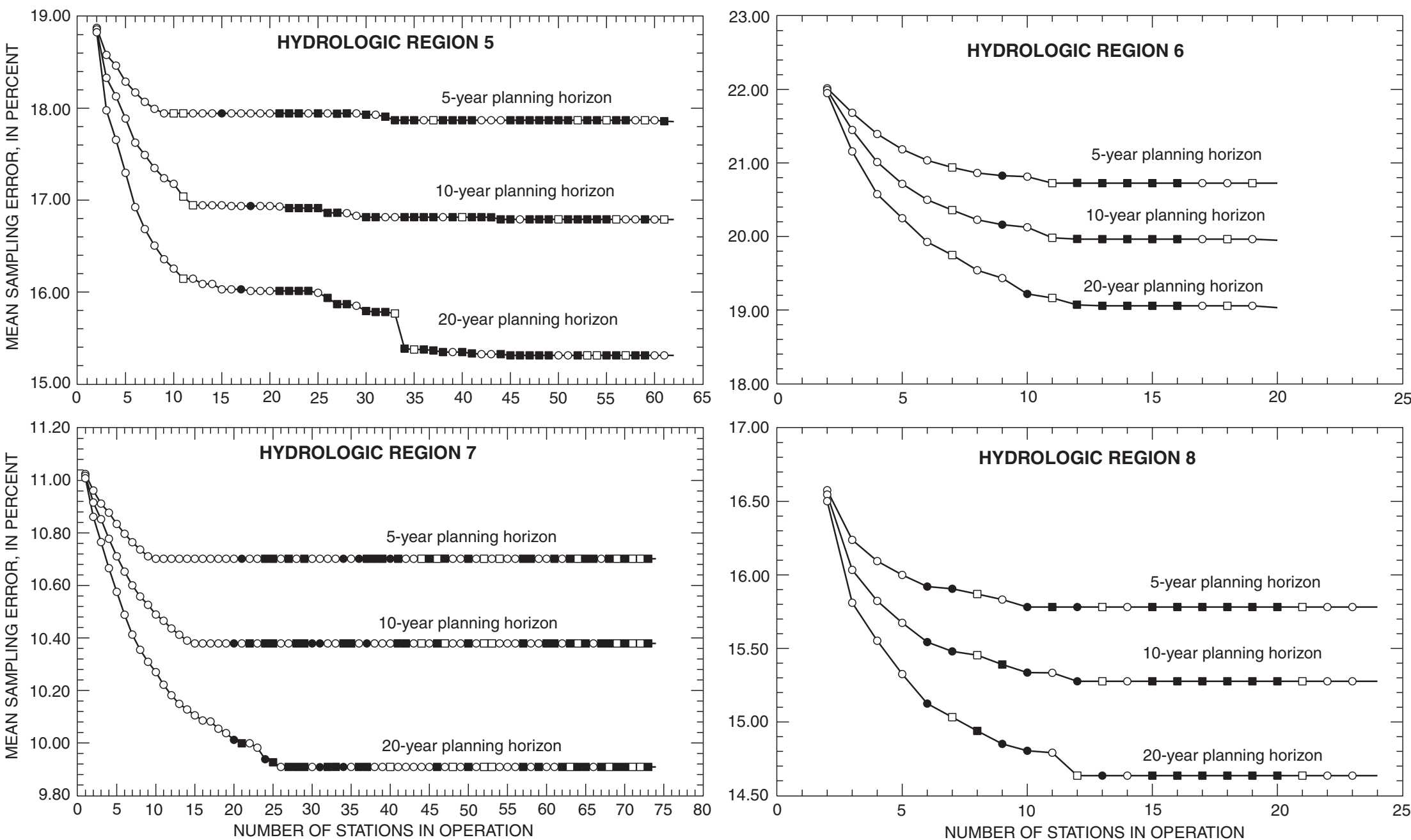

\section{EXPLANATION}

- Discontinued station selected for core network

- Discontinued station not selected for core network
- Active station selected for core network

$\square \quad$ Active station not selected for core network

Figure 8. Relation between mean sampling error, number of streamflow-gaging stations, and planning horizon for 25 -year peak streamflow in hydrologic regions $5-8$. 

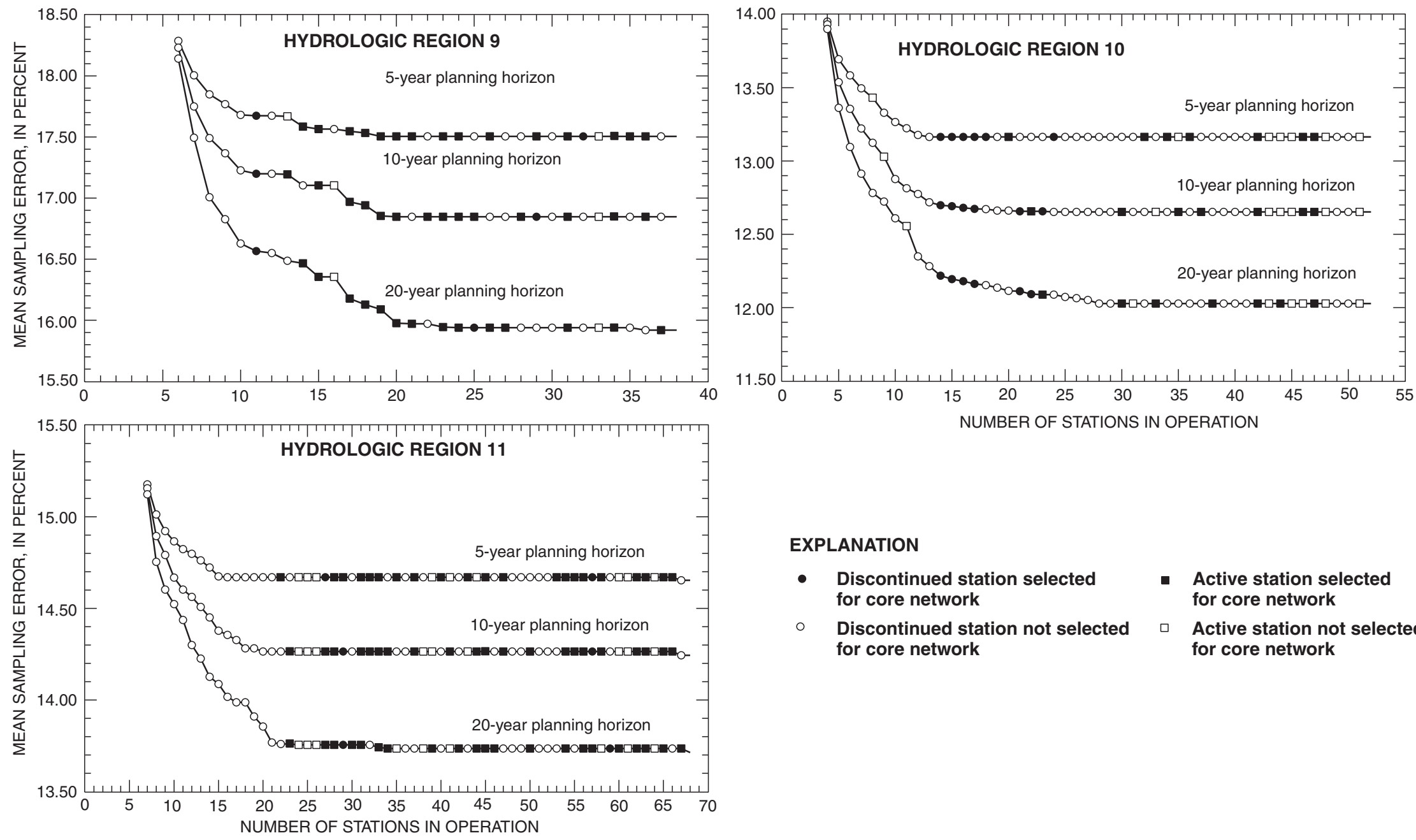

\section{EXPLANATION}

- Discontinued station selected for core network

- Discontinued station not selected for core network
- Active station selected for core network

- Active station not selected for core network

Figure 9. Relation between mean sampling error, number of streamflow-gaging stations, and planning horizon for 25-year peak streamflow in hydrologic regions 9-11. 
The fact that mean sampling error does not decrease as the number of stations operated increases does not mean that nothing can be gained by operating those stations on the flat part of the curve-it means that the expected reduction in regional regression prediction error cannot be forecast accurately. Moreover, data collected at some specific stations on the flat part of the curve can be used for purposes other than regional hydrologic data analysis. What can be determined from the analysis is the rank ordering of stations in terms of their cost effectiveness for providing regional hydrologic information. Those stations on the steepest part of the curves offer the most valuable regional hydrologic information relative to basin characteristics. The ranking of the stations provides a means of deciding which stations should be continued for optimal regional hydrologic information if the budget will not allow all stations to be operated.

The shapes of the curves (figs. 4-9) reveal individual station needs for the planning horizons and indicate relative data needs for the regions. For example, for each region, increasing the duration of the planning horizon increases the number of stations on the steepest part of the curve. This indicates that longer planning horizons require more stations to effectively reduce the sampling error of the data. The scales in the figures for the sampling errors differ for the regions; thus the values of the errors together with the station positions on the error curve are used to determine the most effective stations for the regions and the State.

For the analyses regarding mean annual streamflows (figs. 4-6), regions 1 and 2 (fig. 3) have the largest sampling errors. This is attributed to the physiography and semiarid climate of the two regions. The mean annual precipitation for the regions ranges from about 8 to about 20 inches. Much of the annual precipitation is from a few thunderstorms that produce large areal variations in precipitation depth. Therefore, large variations in storm runoff and annual runoff can occur at the stations. The large variations in runoff cause large sampling errors in the data.

Specific stations in each hydrologic region (except region 2) were identified to be in the core network throughout each of the planning horizons. These were long-term stations that met the regionalization objective and were judged too important to discontinue. Such stations do not exist in region 2. In figures 4-9, the minimum number of gaging stations identified to be in the core network for each hydrologic region is indicated by the plotting position on the horizontal axis (number of stations in operation) of the left-most circle or square symbol. For example, for the 10-year planning horizon for region 1 (fig. 4), 18 stations were considered for the region. The points on the graph show the sampling error for the indicated number of stations included in the network. In the example, the first step of the model includes the full network of 18 stations as shown by the right end of the graph. The next step of the model identifies the station deemed the least important in maintaining a small sampling error, and that station is excluded from the model. The sampling error is then based on the 17 remaining stations, as indicated by the horizontal position of the right-most point on the graph. The rightmost point on the graph represents the first "excluded" station. Three stations were too important to discontinue; thus the left-most circle, which represents the last of the 15 stations eligible to be excluded, is plotted at 3 on the horizontal axis. The three remaining stations in the optimization model provided the most hydrologic information on mean annual flow in terms of basin characteristics for region 1 . If all 15 stations eligible to be excluded in the optimization process were discontinued, the three stations identified to remain active throughout the 10-year planning horizon would provide regional hydrologic information with a mean sampling error of 70.39 percent.

Some stations on the steep part of the curve (figs. 4-9) were not selected to be in the core network because the data are highly correlated with data from adjacent stations, as discussed in the next section. Likewise, some stations on the flat part of the curve are in the core network because they meet one or more objective other than regionalization.

If completely new stations (those without current or historical data) had been considered for the analysis, they probably would rank as most important because the value of data at a new station usually is greater than the value of data from an existing station. However, the location of a station and its basin characteristics also affect the value of the data for regional analysis - a new station located near an existing station might provide redundant data. An existing station that is unlike any other, in terms of basin characteristics, might be more important for regionalization than a new station with redundant basin characteristics.

\section{Flow Correlation}

A statistical test was done on streamflows for existing streamflow-gaging stations to identify the 
strength of association between gaged flows. The test is based on the correlation coefficient for annual mean and annual peak streamflows for proximate stations on the same stream. Candidate station pairs were processed if both stations had data for at least 10 corresponding years with similar basin conditions (regulated or unregulated). If both stations in a pair had corresponding years of unregulated and regulated data, data from both periods were processed. The station pairs were selected by visual inspection of the location of active stations.

For the analysis, 116 station pairs with annual mean flow data were chosen by inspection. Each station pair was located on the same stream or on a stream and its upstream tributary. Some of the stations were paired with more than one other station. Figure 10 shows the ranges of correlation coefficients for annual mean flows between paired stations in the Arkansas, Red, Brazos, Trinity, Neches, Sabine, and San Jacinto drainage basins. Figure 11 shows the ranges in the Colorado, Lavaca, Guadalupe, San Antonio, Nueces, and Rio Grande drainage basins. Figures 12 and 13 show the ranges of coefficients for annual peak flows between paired stations in the same two geographic areas. Tables 1-4 (at end of report) list the correlation coefficients for the paired stations.

Results from the correlation analysis for annual mean flows indicate that 81 station pairs have a coefficient of 0.90 or greater, and 61 of the 81 pairs have correlations of 0.95 or greater. Fewer station pairs exhibited such high correlations for annual peak streamflows. Of the 129 station pairs analyzed for correlation of annual peak flow, 43 pairs have a correlation of 0.90 or greater, and 17 of the 43 pairs have a correlation of 0.95 or greater.

Most of the stations in this analysis are on regulated streams with large drainage areas, thus most meet the major flow objective. Paired stations with an annual mean streamflow correlation coefficient greater than 0.95 were reviewed to identify stations to be excluded from the core network. In some cases, streamflow at one station is highly correlated with streamflow at more than one other station, in which case a single station was selected for the core network. The stations selected for inclusion in the network were those with (1) the longer or longest period of record; (2) water-quality data; and (3) the closer or closest location to the mouth of the stream. Stations proximate to the stream mouth can represent outflow from the basin.

\section{PROPOSED CORE NETWORK}

The evaluation of the existing streamflow-gaging network was used to develop a core network that best meets the four major objectives previously discussed. The proposed core network comprises 263 stations. Table 5 (at end of report) lists the stations in the network and selected characteristics for each station, including the status (active or discontinued); the number of years of record; the contributing drainage area; the hydrologic region; and the objective or objectives for the station's data. Plate 1 shows the locations of the core network stations.

Also identified (see footnote 3 , table 5) is a minimum core network, which is a smaller network designed to meet the objectives. The minimum core network comprises 243 stations and is considered the optimum network that could be operated if the cost of operating the entire core network is prohibitive.

Of the 263 stations in the core network, 43 are discontinued. Additionally, 15 of the 220 active stations are partial-record stations. Each of the major objectives requires streamflow volumes; thus each station in the network must be operated as a daily flow station in order to meet the objectives. Accordingly, to complete the core network, 43 stations would need to be reactivated, and 15 would need to be converted from partial-record status to continuous-record status. Of the 243 stations in the minimum core network, 25 are discontinued, and 14 are partial-record stations.

Many of the proposed core network stations meet more than one objective. Fifty-five of the stations meet two objectives, 16 stations meet three objectives, and 1 station meets all four objectives. A summary of the characteristics for the stations meeting each objective is presented below.

Regionalization: The regional optimization model previously discussed was used to identify the stations providing the most valuable data for each of the hydrologic regions. The stations selected as meeting the regionalization objective for the core network generally are those that contributed the most to reducing the regional regression prediction error-they are the stations on the steepest part of the mean sampling error curve (figs. 4-9). Many of the stations on the steepest part of the curve were not selected for the core network because their streamflows are highly correlated with those of stations that were selected. Of the 352 stations tested in the optimization model, 185 were selected 


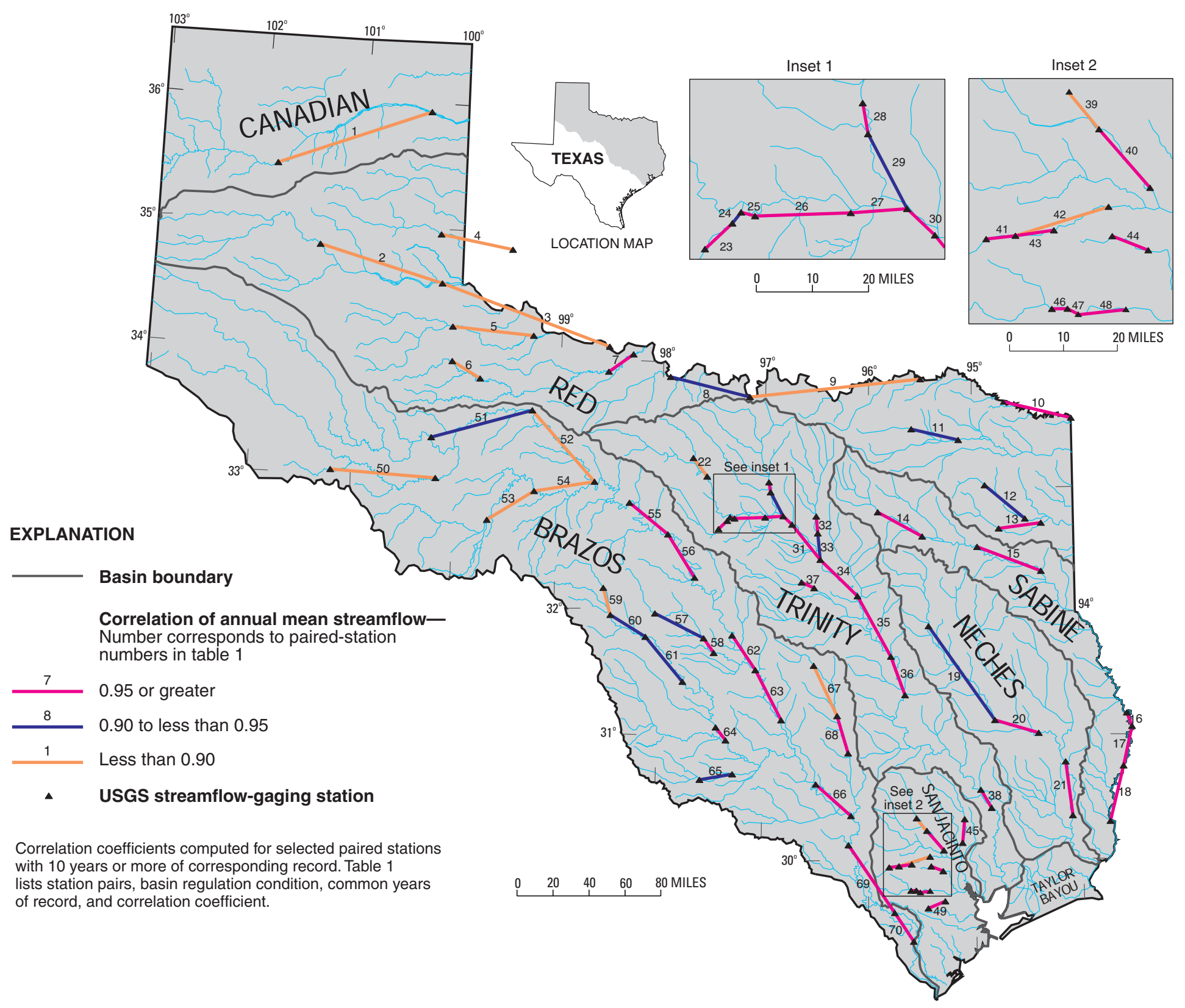

Figure 10. Correlation of annual mean streamflow between paired streamflow-gaging stations in north Texas. 


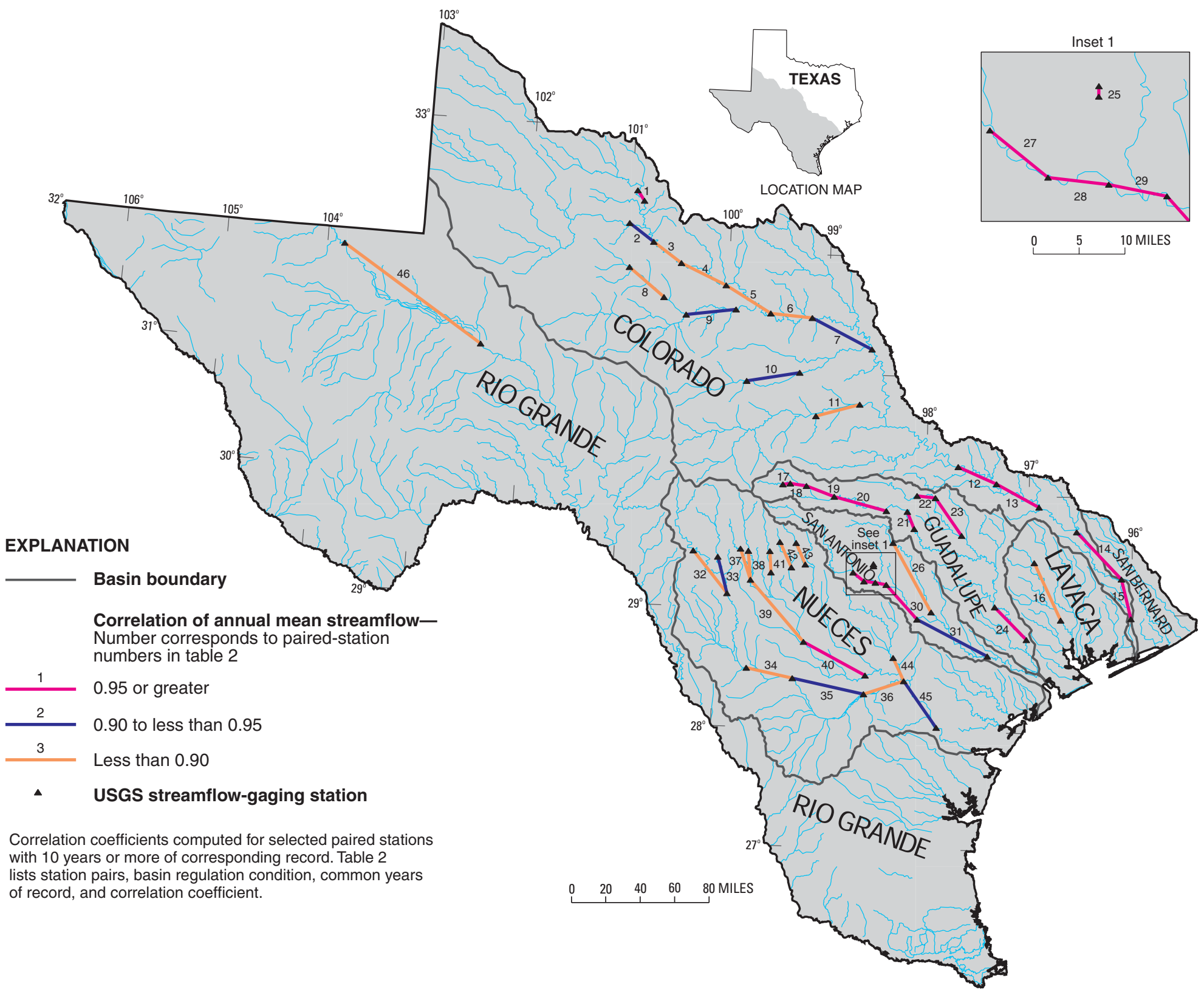

Figure 11. Correlation of annual mean streamflow between paired streamflow-gaging stations in south Texas. 


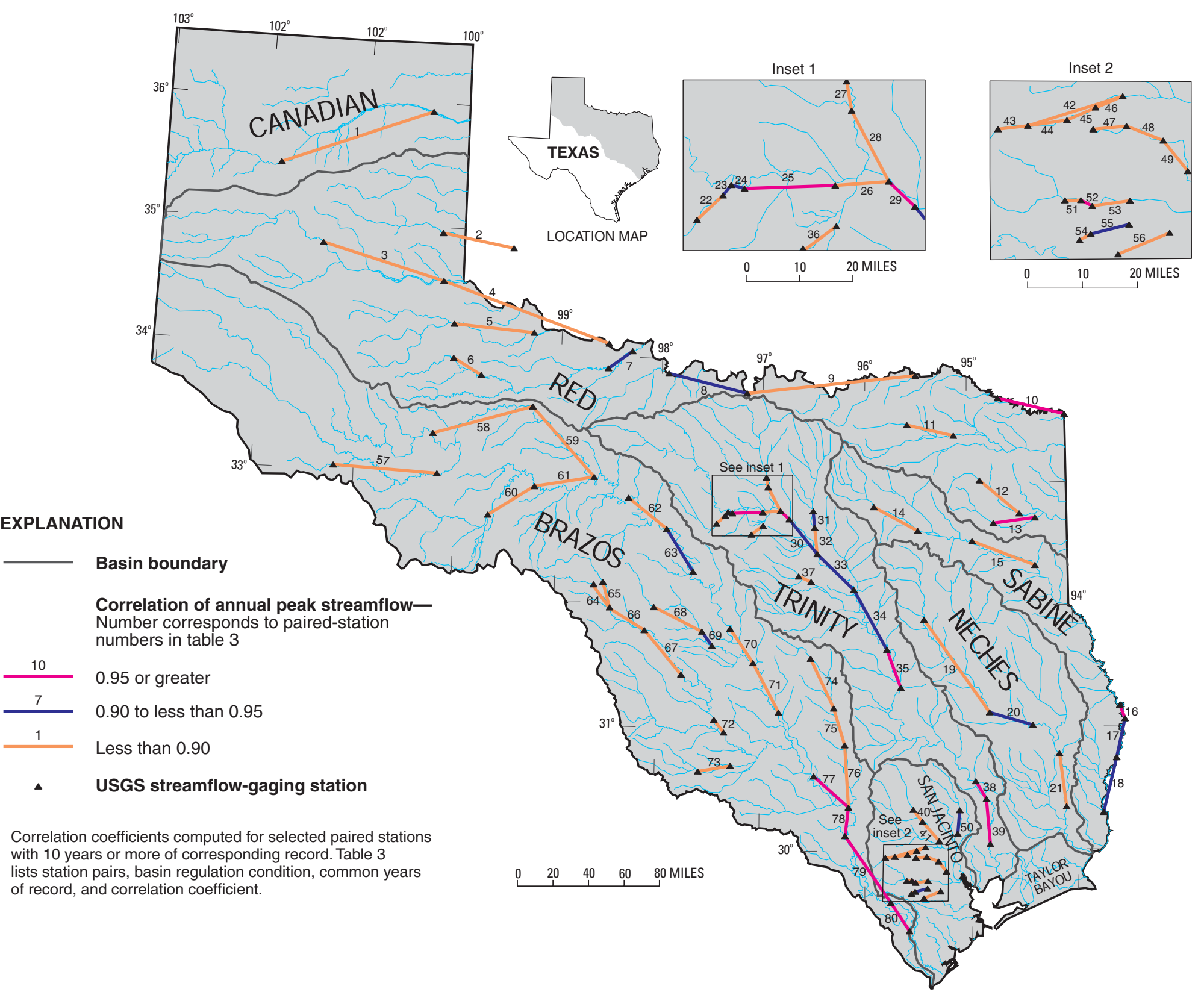

․ Figure 12. Correlation of annual peak streamflow between paired streamflow-gaging stations in north Texas. 


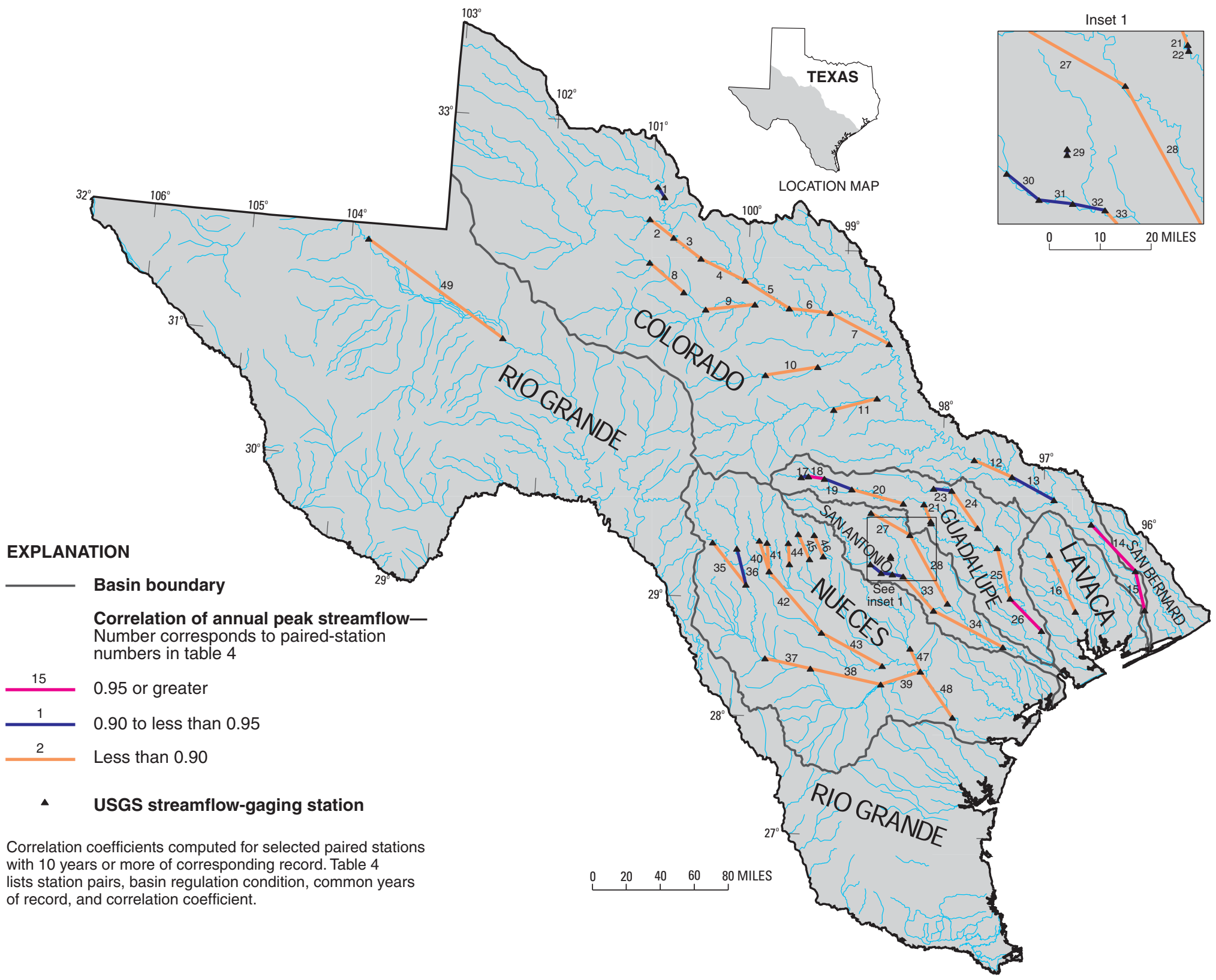

Figure 13. Correlation of annual peak streamflow between paired streamflow-gaging stations in south Texas. 
for the core network - their median length of record is 33 years. Forty-one of the discontinued stations in the core network meet the regionalization objective. The number of regionalization stations in each hydrologic region ranges from 7 stations in region 6 to 28 stations in region 5.

Major Flow: With the exception of Taylor Bayou and the San Bernard and Lavaca River Basins, major flow stations are in each of the 15 major river basins identified on plate 1 . The flow characteristics and water use vary along many of the major streams in Texas, especially the Red, Sabine, Trinity, Brazos, and Colorado Rivers. Therefore, streamflow-gaging stations are needed at many sites along the rivers. Ninety-two major flow stations are identified in the core network. The median length of record for these stations is about 62 years, and only four of the stations are discontinued. The number of stations with upstream basins greater than 1,000 square miles that were active as of October 1,1999 , is about 140; therefore 50 of these existing stations are not included in the core network. Most of the stations were excluded from the network as a result of the flow-correlation analysis.

Outflow from the State: Twenty-one streams that flow out of the State were identified. Only one of those streams, the Sulphur River, is not gaged for outflow. The Sulphur River crosses the State border just downstream from Lake Texarkana (pl. 1). The stream reach downstream from the reservoir frequently is in backwater from another river, thus cannot be gaged for streamflow without great expense. However, as of 1999, the USACE determines outflow from Lake Texarkana. Those data can be used to represent State outflow from the Sulphur River Basin.

Because of backwater from the Gulf of Mexico or other water bodies, some stations are located upstream from the mouths of streams. In some cases these stations also are upstream from large tributaries to the outflow streams. Therefore, the sum of gaged flows on the main channel and the tributary or tributaries can be used to compute basin outflow. Such is the case for Cypress Creek (three stations) and the Neches River (three stations). Two stations gage outflow from the Sabine and Guadalupe Rivers. One station on the Sabine is just upstream from where the river becomes a state border with Louisiana, and the other station is near the mouth of the river at the Gulf of Mexico. For the Guadalupe River, one station is near the mouth where streamflow gaging sometimes is complicated by backwater from the
Gulf of Mexico, and the other station is farther upstream. For the other outflow streams, one station is used to gage each outflow from the State. Twenty-six stations, with a median record length of 59 years, were selected as meeting this objective. All these stations were active as of October 1, 1999, and included in the core network.

Streamflow Condition Assessment: Fifty stations were selected as meeting this objective in the core network, each of which was active as of October 1, 1999. Each of these stations also meets the regionalization objective. The median length of record for these stations is 53 years. The number of stations within each hydrologic region ranges from two stations in region 8 to seven stations in regions 9 and 11 .

The USGS presents an on-line assessment of streamflow conditions based on data from stations that have at least 30 years of data. The assessment presents, for each station, near real-time flow conditions as a percentile of its historical data. The assessment is at http://water.usgs.gov/tx/nwis/rt.

\section{SUMMARY}

The USGS streamflow-gaging network in Texas is operated as part of the National Streamgaging Program and is jointly funded by the USGS and Federal, State, and local agencies. The streamflow-gaging network has changed substantially during the more than 100 years since its inception. The network began with a few stations in the 1890s, peaked at about 650 stations in the 1970s, and currently (1999) is about one-half that size.

This report documents an evaluation of the existing (as of October 1, 1999) network with regard to four major objectives of streamflow data; and on the basis of that evaluation, proposes a core network of streamflowgaging stations that best meets those objectives. The objectives are (1) regionalization (estimate flows or flow characteristics at ungaged sites in 11 hydrologically similar regions), (2) major flow (obtain flow rates and volumes in major streams), (3) outflow from the State (account for streamflow leaving the State), and (4) streamflow conditions assessment (assess current conditions with regard to long-term data, and define temporal trends). Simple definition tests were sufficient to identify stations that met the criteria for major flow, outflow from the State, and streamflow conditions assessment. A regional optimization model (in addition to hydrologic region boundaries) was used to determine 
whether stations met the regionalization objective. The optimization model maximizes the value of the gagingstation data and minimizes the cost of obtaining the data, thus optimizing the network on the basis of value and expense. Among the stations that met at least one of the four network objectives, flow correlation analysis was used to identify stations that provide redundant flow data. Paired stations that were highly correlated (annual mean streamflow correlation coefficient greater than 0.95) were reviewed. A single station was selected for the core network from groups of two or more highly correlated stations.

The network analysis resulted in a proposed core network of 263 stations. Of those 263 stations, 43 were discontinued as of October 1, 1999, and 15 were partialrecord stations. Thus, implementation of the core network would require reactivation of 43 stations and conversion of 15 stations from partial record to continuous record. Fifty-five of the proposed core-network stations meet two of the four major objectives, 16 stations meet three objectives, and 1 station meets all four.

One-hundred eighty-five stations with a median record length of 33 years were selected to meet the regionalization objective. The number of regionalization stations in each hydrologic region ranges from 7 to 28. Ninety-two stations with a median record length of about 62 years were selected to meet the major-flow objective. Major-flow stations are in 12 of the State's 15 major river basins. Twenty-six stations with a median record length of 59 years were selected to meet the outflow from the State objective. Although only 21 streams that flow out of the State were identified, gaging stations on large tributaries are needed in basins where main-stem gages are upstream of the tributarymain stem confluence. Fifty stations with a median record length of 53 years were selected to meet the streamflow-conditions-assessment objective. The number of streamflow-conditions-assessment stations in each hydrologic region ranges from two to seven.

\section{REFERENCES}

Asquith, W.H., and Slade, R.M., Jr., 1995, Documented and potential extreme peak discharges and relation between potential extreme peak discharges and probable maximum flood peak discharges in Texas: U.S. Geological Survey Water-Resources Investigations Report 95-4249, 58 p.

1997, Regional equations for estimation of peakstreamflow frequency for natural basins in Texas: U.S. Geological Survey Water-Resources Investigations Report 96-4307, 68 p.

Carr, J.T., Jr., 1967, The climate and physiography of Texas: Texas Water Development Board Report 53, 27 p.

Gilbert, C.R., and Hawkinson, R.O., 1971, A proposed streamflow data program for Texas: U.S. Geological Survey Open-File report, $52 \mathrm{p}$.

Judd, L.J., 1995, Streamflow to the Gulf of Mexico: U.S. Geological Survey Water-Resources Investigations Report 95-4054, 27 p.

Kier, R.S., Garner, L.E., and Brown, L.F., Jr., 1977, Land resources of Texas: Austin, University of Texas, Bureau of Economic Geology, 41 p.

Lanning-Rush, Jennifer, 2000, Regional equations for estimating mean annual and mean seasonal runoff for natural basins in Texas, base period 1961-90: U.S. Geological Survey Water-Resources Investigations Report 00-4604, 27 p.

Massey, B.C., 1985, Texas stream-gaging program-An analysis of data uses and funding: U.S. Geological Survey Open-File Report 85-084, 40 p.

Schroeder, E.E., and Massey, B.C., 1977, Technique for estimating the magnitude and frequency of floods in Texas: U.S. Geological Survey Water-Resources Investigations Report 77-110, 22 p.

Slade, R.M., Jr., 1992, Status of the Gulf of MexicoPreliminary report on inflow from streams: U.S. Environmental Protection Agency Report 800-R-92-005, $64 \mathrm{p}$.

Stedinger, J.R., and Tasker, G.D., 1985, Regional hydrologic analysis - 1 . Ordinary, weighted, and generalized least squares compared: Water Resources Research, v. 21, no. 9 , p. 1,421-1,432.

Tasker, G.D., and Stedinger, J.R., 1989, An operational GLS model for hydrologic regression: Journal of Hydrology, v. 111, p. 361-375.

Texas Board of Water Engineers, 1960, Texas stream-gaging program, evaluation and recommendations: Texas Board of Water Engineers Bulletin 5807-E, 31 p. 
Table 1. Correlation coefficients of annual mean streamflows for paired stations in north Texas basins [USGS, U.S. Geological Survey; R, regulated; U, unregulated]

\begin{tabular}{|c|c|c|c|c|c|}
\hline $\begin{array}{l}\text { Station } \\
\text { pair no. } \\
\text { (fig. 10) }\end{array}$ & $\begin{array}{c}\text { USGS } \\
\text { upstream } \\
\text { station no. }\end{array}$ & $\begin{array}{c}\text { USGS } \\
\text { downstream } \\
\text { station no. }\end{array}$ & $\begin{array}{l}\text { Basin } \\
\text { regulation } \\
\text { condition }\end{array}$ & $\begin{array}{c}\text { Common } \\
\text { years of } \\
\text { record }\end{array}$ & $\begin{array}{l}\text { Correlation } \\
\text { coefficient }\end{array}$ \\
\hline 1 & 07227500 & 07228000 & $\mathrm{R}$ & 33 & 0.382 \\
\hline 2 & 07297910 & 07299540 & $\mathrm{U}$ & 11 & .768 \\
\hline 3 & 07299540 & 07308500 & $\mathrm{R}$ & 13 & .687 \\
\hline 4 & 07300000 & 07300500 & $\mathrm{R}$ & 44 & .697 \\
\hline 5 & 07307800 & 07308200 & $\mathrm{U}$ & 21 & .822 \\
\hline 6 & 07311600 & 07311700 & $\mathrm{R}$ & 23 & .753 \\
\hline 7 & 07312500 & 07312700 & $\mathrm{R}$ & 29 & .983 \\
\hline 8 & 07315500 & 07316000 & $\mathrm{R}$ & 58 & .939 \\
\hline 9 & 07316000 & 07335500 & $\mathrm{R}$ & 60 & .811 \\
\hline 10 & 07336820 & 07337000 & $\mathrm{R}$ & 26 & .978 \\
\hline 11 & 07343000 & 07343200 & $\mathrm{R}$ & 35 & .902 \\
\hline 12 & 07344500 & 07346000 & $\mathrm{R}$ & 29 & .934 \\
\hline 13 & 07346050 & 07346070 & $\mathrm{R}$ & 33 & .981 \\
\hline 14 & 08017410 & 08018500 & $\mathrm{R}$ & 26 & .966 \\
\hline 15 & 08020000 & 08022040 & $\mathrm{R}$ & 18 & .978 \\
\hline 16 & 08025360 & 08026000 & $\mathrm{R}$ & 22 & .999 \\
\hline 17 & 08026000 & 08028500 & $\mathrm{R}$ & 41 & .992 \\
\hline 18 & 08028500 & 08030500 & $\mathrm{R}$ & 71 & .993 \\
\hline 19 & 08032000 & 08033000 & $\mathrm{R}$ & 46 & .909 \\
\hline 20 & 08033000 & 08033500 & $\mathrm{R}$ & 48 & .986 \\
\hline 21 & 08040600 & 08041000 & $\mathrm{R}$ & 7 & .999 \\
\hline 22 & 08044000 & 08044500 & $\mathrm{R}$ & 40 & .801 \\
\hline 23 & 08047000 & 08047500 & $\mathrm{R}$ & 49 & .963 \\
\hline 24 & 08047500 & 08048000 & $\mathrm{R}$ & 51 & .901 \\
\hline 25 & 08048000 & 08048543 & $\mathrm{R}$ & 16 & .996 \\
\hline 26 & 08048543 & 08049500 & $\mathrm{R}$ & 16 & .989 \\
\hline 27 & 08049500 & 08057000 & $\mathrm{R}$ & 69 & .965 \\
\hline 28 & 08053000 & 08055500 & $\mathrm{R}$ & 45 & .981 \\
\hline 29 & 08055500 & 08057000 & $\mathrm{R}$ & 56 & .934 \\
\hline 30 & 08057000 & 08057410 & $\mathrm{R}$ & 39 & .995 \\
\hline 31 & 08057410 & 08062500 & $\mathrm{R}$ & 39 & .986 \\
\hline 32 & 08061750 & 08062000 & $\mathrm{R}$ & 22 & .996 \\
\hline 33 & 08062000 & 08062500 & $\mathrm{R}$ & 46 & .922 \\
\hline 34 & 08062500 & 08062700 & $\mathrm{R}$ & 32 & .989 \\
\hline 35 & 08062700 & 08065000 & $\mathrm{R}$ & 32 & .980 \\
\hline
\end{tabular}


Table 1. Correlation coefficients of annual mean streamflows for paired stations in north Texas basins-Continued

\begin{tabular}{|c|c|c|c|c|c|}
\hline $\begin{array}{l}\text { Station } \\
\text { pair no. } \\
\text { (fig. 10) }\end{array}$ & $\begin{array}{c}\text { USGS } \\
\text { upstream } \\
\text { station no. }\end{array}$ & $\begin{array}{c}\text { USGS } \\
\text { downstream } \\
\text { station no. }\end{array}$ & $\begin{array}{l}\text { Basin } \\
\text { regulation } \\
\text { condition }\end{array}$ & $\begin{array}{l}\text { Common } \\
\text { years of } \\
\text { record }\end{array}$ & $\begin{array}{l}\text { Correlation } \\
\text { coefficient }\end{array}$ \\
\hline 36 & 08065000 & 08065350 & $\mathrm{R}$ & 33 & 0.996 \\
\hline 37 & 08063800 & 08064100 & $\mathrm{R}$ & 13 & .964 \\
\hline 38 & 08066250 & 08066500 & $\mathrm{R}$ & 30 & .998 \\
\hline 39 & 08067650 & 08068000 & $\mathrm{R}$ & 14 & .870 \\
\hline 40 & 08068000 & 08068090 & $\mathrm{R}$ & 12 & .994 \\
\hline 41 & 08068720 & 08068740 & $\mathrm{R}$ & 19 & .986 \\
\hline 42 & 08068740 & 08069000 & $\mathrm{R}$ & 21 & .892 \\
\hline 43 & 08068740 & 08068800 & $\mathrm{R}$ & 13 & .974 \\
\hline 44 & 08075900 & 08076000 & $\mathrm{U}$ & 28 & .969 \\
\hline 45 & 08070000 & 08070200 & $\mathrm{R}$ & 12 & .986 \\
\hline 46 & 08073500 & 08073600 & $\mathrm{R}$ & 18 & .997 \\
\hline 47 & 08073600 & 08073700 & $\mathrm{R}$ & 16 & .999 \\
\hline 48 & 08073700 & 08074000 & $\mathrm{R}$ & 11 & .996 \\
\hline 49 & 08075400 & 08075500 & $\mathrm{U}$ & 26 & .975 \\
\hline 50 & 08079600 & 08080500 & $\mathrm{U}$ & 34 & .719 \\
\hline 51 & 08082000 & 08082500 & $\mathrm{R}$ & 47 & .904 \\
\hline 52 & 08082500 & 08088000 & $\mathrm{R}$ & 46 & .883 \\
\hline 53 & 08084000 & 08085500 & $\mathrm{R}$ & 72 & .866 \\
\hline 54 & 08085500 & 08088000 & $\mathrm{R}$ & 36 & .839 \\
\hline 55 & 08089000 & 08090800 & $\mathrm{R}$ & 28 & .976 \\
\hline 56 & 08090800 & 08091000 & $\mathrm{R}$ & 28 & .989 \\
\hline 57 & 08094800 & 08095000 & $\mathrm{R}$ & 29 & .918 \\
\hline 58 & 08095000 & 08095200 & $\mathrm{R}$ & 37 & .991 \\
\hline 59 & 08099100 & 08099500 & $\mathrm{R}$ & 26 & .805 \\
\hline 60 & 08099500 & 08100000 & $\mathrm{R}$ & 30 & .930 \\
\hline 61 & 08100000 & 08100500 & $\mathrm{R}$ & 33 & .915 \\
\hline 62 & 08093100 & 08096500 & $\mathrm{R}$ & 21 & .980 \\
\hline 63 & 08096500 & 08098290 & $\mathrm{R}$ & 30 & .990 \\
\hline 64 & 08102500 & 08104500 & $\mathrm{R}$ & 39 & .951 \\
\hline 65 & 08105300 & 08105700 & $\mathrm{R}$ & 11 & .928 \\
\hline 66 & 08109000 & 08110200 & $\mathrm{R}$ & 17 & .985 \\
\hline 67 & 08110325 & 08110500 & $\mathrm{R}$ & 17 & .776 \\
\hline 68 & 08110500 & 08111000 & $\mathrm{R}$ & 43 & .982 \\
\hline 69 & 08111500 & 08114000 & $\mathrm{R}$ & 58 & .997 \\
\hline 70 & 08114000 & 08116650 & $\mathrm{R}$ & 25 & .997 \\
\hline
\end{tabular}


Table 2. Correlation coefficients of annual mean streamflows for paired stations in south Texas basins

[USGS, U.S. Geological Survey; R, regulated; U, unregulated]

\begin{tabular}{|c|c|c|c|c|c|}
\hline $\begin{array}{l}\text { Station } \\
\text { pair no. } \\
\text { (fig. 11) }\end{array}$ & $\begin{array}{c}\text { USGS } \\
\text { upstream } \\
\text { station no. }\end{array}$ & $\begin{array}{c}\text { USGS } \\
\text { downstream } \\
\text { station no. }\end{array}$ & $\begin{array}{c}\text { Basin } \\
\text { regulation } \\
\text { condition }\end{array}$ & $\begin{array}{l}\text { Common years } \\
\text { of record }\end{array}$ & $\begin{array}{l}\text { Correlation } \\
\text { coefficient }\end{array}$ \\
\hline 1 & 08120700 & 08121000 & $\mathrm{R}$ & 30 & 0.952 \\
\hline 2 & 08123800 & 08123850 & $\mathrm{R}$ & 29 & .914 \\
\hline 3 & 08123850 & 08124000 & $\mathrm{R}$ & 28 & .259 \\
\hline 4 & 08124000 & 08126380 & $\mathrm{R}$ & 17 & .616 \\
\hline 5 & 08126380 & 08136700 & $\mathrm{R}$ & 17 & .794 \\
\hline 6 & 08136700 & 08138000 & $\mathrm{R}$ & 25 & .887 \\
\hline 7 & 08138000 & 08147000 & $\mathrm{R}$ & 64 & .911 \\
\hline 8 & 08133500 & 08134000 & $\mathrm{R}$ & 46 & .786 \\
\hline 9 & 08136000 & 08136500 & $\mathrm{R}$ & 81 & .922 \\
\hline 10 & 08144500 & 08144600 & $\mathrm{R}$ & 14 & .938 \\
\hline 11 & 08150800 & 08151500 & $\mathrm{R}$ & 33 & .803 \\
\hline 12 & 08158000 & 08159200 & $\mathrm{R}$ & 36 & .985 \\
\hline 13 & 08159200 & 08160400 & $\mathrm{R}$ & 8 & .993 \\
\hline 14 & 08161000 & 08162000 & $\mathrm{R}$ & 58 & .992 \\
\hline 15 & 08162000 & 08162500 & $\mathrm{R}$ & 48 & .992 \\
\hline 16 & 08163500 & 08164000 & $\mathrm{U}$ & 53 & .895 \\
\hline 17 & 08165300 & 08165500 & $\mathrm{U}$ & 29 & .961 \\
\hline 18 & 08165500 & 08166200 & $\mathrm{U}$ & 10 & .987 \\
\hline 19 & 08166200 & 08167000 & $\mathrm{U}$ & 10 & .981 \\
\hline 20 & 08167000 & 08167500 & $\mathrm{U}$ & 57 & .967 \\
\hline 21 & 08167800 & 08168500 & $\mathrm{R}$ & 36 & .993 \\
\hline 22 & 08171000 & 08171300 & $\mathrm{R}$ & 40 & .990 \\
\hline 23 & 08171300 & 08172000 & $\mathrm{R}$ & 27 & .966 \\
\hline 24 & 08175800 & 08176500 & $\mathrm{R}$ & 32 & .999 \\
\hline 25 & 08178000 & 08178050 & $\mathrm{R}$ & 4 & .998 \\
\hline 26 & 08185000 & 08186000 & $\mathrm{R}$ & 34 & .712 \\
\hline 27 & 08180700 & 08180800 & $\mathrm{R}$ & 14 & .988 \\
\hline 28 & 08180800 & 08181500 & $\mathrm{R}$ & 25 & .988 \\
\hline 29 & 08181500 & 08181800 & $\mathrm{R}$ & 34 & .979 \\
\hline 30 & 08181800 & 08183500 & $\mathrm{R}$ & 34 & .982 \\
\hline 31 & 08183500 & 08188500 & $\mathrm{R}$ & 60 & .923 \\
\hline 32 & 08190500 & 08192000 & $\mathrm{U}$ & 51 & .722 \\
\hline 33 & 08190000 & 08192000 & $\mathrm{U}$ & 57 & .923 \\
\hline 34 & 08193000 & 08194000 & $\mathrm{R}$ & 57 & .874 \\
\hline 35 & 08194000 & 08194500 & $\mathrm{R}$ & 53 & .915 \\
\hline 36 & 08194500 & 08210000 & $\mathrm{R}$ & 15 & .839 \\
\hline 37 & 08196000 & 08197500 & $\mathrm{R}$ & 43 & .777 \\
\hline 38 & 08195000 & 08197500 & $\mathrm{R}$ & 43 & .780 \\
\hline 39 & 08197500 & 08205500 & $\mathrm{R}$ & 43 & .685 \\
\hline 40 & 08205500 & 08206600 & $\mathrm{R}$ & 18 & .964 \\
\hline 41 & 08198000 & 08198500 & $\mathrm{R}$ & 44 & .827 \\
\hline 42 & 08201500 & 08202700 & $\mathrm{R}$ & 35 & .532 \\
\hline 43 & 08200000 & 08200700 & $\mathrm{R}$ & 36 & .787 \\
\hline 44 & 08208000 & 08210000 & $\mathrm{R}$ & 53 & .708 \\
\hline 45 & 08210000 & 08211000 & $\mathrm{R}$ & 10 & .935 \\
\hline 46 & 08412500 & 08446500 & $\mathrm{R}$ & 54 & .775 \\
\hline
\end{tabular}


Table 3. Correlation coefficients of annual peak streamflows for paired stations in north Texas basins

[USGS, U.S. Geological Survey; R, regulated; U, unregulated]

\begin{tabular}{|c|c|c|c|c|c|}
\hline $\begin{array}{l}\text { Station } \\
\text { pair no. } \\
\text { (fig. 12) }\end{array}$ & $\begin{array}{c}\text { USGS } \\
\text { upstream } \\
\text { station no. }\end{array}$ & $\begin{array}{c}\text { USGS } \\
\text { downstream } \\
\text { station no. }\end{array}$ & $\begin{array}{c}\text { Basin } \\
\text { regulation } \\
\text { condition }\end{array}$ & $\begin{array}{c}\text { Common years } \\
\text { of record }\end{array}$ & $\begin{array}{l}\text { Correlation } \\
\text { coefficient }\end{array}$ \\
\hline 1 & 07227500 & 07228000 & $\overline{\mathrm{R}}$ & 34 & 0.181 \\
\hline 2 & 07300000 & 07300500 & $\mathrm{R}$ & 15 & .847 \\
\hline 3 & 07297910 & 07299540 & $\mathrm{U}$ & 11 & .438 \\
\hline 4 & 07299540 & 07308500 & $\mathrm{R}$ & 14 & .367 \\
\hline 5 & 07307800 & 07308200 & $\mathrm{U}$ & 30 & .523 \\
\hline 6 & 07311600 & 07311700 & $\mathrm{R}$ & 23 & .685 \\
\hline 7 & 07312500 & 07312700 & $\mathrm{R}$ & 29 & .939 \\
\hline 8 & 07315500 & 07316000 & $\mathrm{R}$ & 48 & .945 \\
\hline 9 & 07316000 & 07335500 & $\mathrm{R}$ & 10 & .726 \\
\hline 10 & 07336820 & 07337000 & $\mathrm{R}$ & 25 & .967 \\
\hline 11 & 07343000 & 07343200 & $\mathrm{R}$ & 35 & .823 \\
\hline 12 & 07344500 & 07346000 & $\mathrm{R}$ & 32 & .606 \\
\hline 13 & 07346050 & 07346070 & $\mathrm{R}$ & 34 & .958 \\
\hline 14 & 08017410 & 08018500 & $\mathrm{R}$ & 26 & .835 \\
\hline 15 & 08020000 & 08022040 & $\mathrm{R}$ & 18 & .836 \\
\hline 16 & 08025360 & 08026000 & $\mathrm{R}$ & 22 & .983 \\
\hline 17 & 08026000 & 08028500 & $\mathrm{R}$ & 41 & .934 \\
\hline 18 & 08028500 & 08030500 & $\mathrm{R}$ & 72 & .910 \\
\hline 19 & 08032000 & 08033000 & $\mathrm{R}$ & 57 & .700 \\
\hline 20 & 08033000 & 08033500 & $\mathrm{R}$ & 60 & .941 \\
\hline 21 & 08040600 & 08041000 & $\mathrm{R}$ & 7 & .870 \\
\hline 22 & 08047000 & 08047500 & $\mathrm{R}$ & 49 & .703 \\
\hline 23 & 08047500 & 08048000 & $\mathrm{R}$ & 53 & .920 \\
\hline 24 & 08048000 & 08048543 & $\mathrm{R}$ & 16 & .938 \\
\hline 25 & 08048543 & 08049500 & $\mathrm{R}$ & 16 & .961 \\
\hline 26 & 08049500 & 08057000 & $\mathrm{R}$ & 70 & .874 \\
\hline 27 & 08053000 & 08055500 & $\mathrm{R}$ & 45 & .870 \\
\hline 28 & 08055500 & 08057000 & $\mathrm{R}$ & 56 & .745 \\
\hline 29 & 08057000 & 08057410 & $\mathrm{R}$ & 40 & .973 \\
\hline 30 & 08057410 & 08062500 & $\mathrm{R}$ & 40 & .943 \\
\hline 31 & 08061750 & 08062000 & $\mathrm{R}$ & 22 & .917 \\
\hline 32 & 08062000 & 08062500 & $\mathrm{R}$ & 46 & .874 \\
\hline 33 & 08062500 & 08062700 & $\mathrm{R}$ & 32 & .920 \\
\hline 34 & 08062700 & 08065000 & $\mathrm{R}$ & 32 & .943 \\
\hline 35 & 08065000 & 08065350 & $\mathrm{R}$ & 33 & .985 \\
\hline 36 & 08049580 & 08049700 & $\mathrm{R}$ & 11 & .875 \\
\hline 37 & 08063800 & 08064100 & $\mathrm{R}$ & 13 & .783 \\
\hline 38 & 08066250 & 08066500 & $\mathrm{R}$ & 31 & .993 \\
\hline 39 & 08066500 & 08067000 & $\mathrm{R}$ & 52 & .985 \\
\hline 40 & 08067650 & 08068000 & $\mathrm{R}$ & 21 & .637 \\
\hline
\end{tabular}


Table 3. Correlation coefficients of annual peak streamflows for paired stations in north Texas basins-Continued

\begin{tabular}{|c|c|c|c|c|c|}
\hline $\begin{array}{l}\text { Station } \\
\text { pair no. } \\
\text { (fig. 12) }\end{array}$ & $\begin{array}{c}\text { USGS } \\
\text { upstream } \\
\text { station no. }\end{array}$ & $\begin{array}{c}\text { USGS } \\
\text { downstream } \\
\text { station no. }\end{array}$ & $\begin{array}{c}\text { Basin } \\
\text { regulation } \\
\text { condition }\end{array}$ & $\begin{array}{c}\text { Common years } \\
\text { of record }\end{array}$ & $\begin{array}{l}\text { Correlation } \\
\text { coefficient }\end{array}$ \\
\hline 41 & 08068000 & 08068090 & $\bar{R}$ & 12 & 0.864 \\
\hline 42 & 08068740 & 08069000 & $\mathrm{R}$ & 22 & .493 \\
\hline 43 & 08068720 & 08068740 & $\mathrm{R}$ & 21 & .879 \\
\hline 44 & 08068740 & 08068800 & $\mathrm{R}$ & 14 & .899 \\
\hline 45 & 08068800 & 08069000 & $\mathrm{R}$ & 14 & .764 \\
\hline 46 & 08068900 & 08069000 & $\mathrm{R}$ & 10 & .868 \\
\hline 47 & 08075780 & 08075900 & $\mathrm{R}$ & 31 & .686 \\
\hline 48 & 08075900 & 08076000 & $\mathrm{R}$ & 31 & .833 \\
\hline 49 & 08076000 & 08076700 & $\mathrm{R}$ & 23 & .833 \\
\hline 50 & 08070000 & 08070200 & $\mathrm{R}$ & 12 & .943 \\
\hline 51 & 08073500 & 08073600 & $\mathrm{R}$ & 18 & .882 \\
\hline 52 & 08073600 & 08073700 & $\mathrm{R}$ & 13 & .972 \\
\hline 53 & 08073700 & 08074000 & $\mathrm{R}$ & 26 & .869 \\
\hline 54 & 08074800 & 08074810 & $\mathrm{R}$ & 19 & .873 \\
\hline 55 & 08074810 & 08075000 & $\mathrm{R}$ & 20 & .935 \\
\hline 56 & 08075400 & 08075500 & $\mathrm{R}$ & 32 & .747 \\
\hline 57 & 08079600 & 08080500 & $\mathrm{U}$ & 35 & .655 \\
\hline 58 & 08082000 & 08082500 & $\mathrm{R}$ & 50 & .692 \\
\hline 59 & 08082500 & 08088000 & $\mathrm{R}$ & 46 & .730 \\
\hline 60 & 08084000 & 08085500 & $\mathrm{R}$ & 73 & .697 \\
\hline 61 & 08085500 & 08088000 & $\mathrm{R}$ & 36 & .713 \\
\hline 62 & 08089000 & 08090800 & $\mathrm{R}$ & 28 & .874 \\
\hline 63 & 08090800 & 08091000 & $\mathrm{R}$ & 28 & .919 \\
\hline 64 & 08099300 & 08099500 & $\mathrm{R}$ & 12 & .670 \\
\hline 65 & 08099100 & 08099500 & $\mathrm{R}$ & 31 & .539 \\
\hline 66 & 08099500 & 08100000 & $\mathrm{R}$ & 30 & .658 \\
\hline 67 & 08100000 & 08100500 & $\mathrm{R}$ & 33 & .721 \\
\hline 68 & 08094800 & 08095000 & $\mathrm{R}$ & 30 & .666 \\
\hline 69 & 08095000 & 08095200 & $\mathrm{R}$ & 37 & .940 \\
\hline 70 & 08093100 & 08096500 & $\mathrm{R}$ & 21 & .780 \\
\hline 71 & 08096500 & 08098290 & $\mathrm{R}$ & 30 & .713 \\
\hline 72 & 08102500 & 08104500 & $\mathrm{R}$ & 39 & .623 \\
\hline 73 & 08105300 & 08105700 & $\mathrm{R}$ & 11 & .376 \\
\hline 74 & 08110325 & 08110500 & $\mathrm{R}$ & 17 & .813 \\
\hline 75 & 08110500 & 08111000 & $\mathrm{R}$ & 46 & .834 \\
\hline 76 & 08111000 & 08110200 & $\mathrm{R}$ & 18 & .831 \\
\hline 77 & 08109000 & 08110200 & $\mathrm{R}$ & 18 & .967 \\
\hline 78 & 08110200 & 08111500 & $\mathrm{R}$ & 18 & .973 \\
\hline 79 & 08111500 & 08114000 & $\mathrm{R}$ & 58 & .968 \\
\hline 80 & 08114000 & 08116650 & $\mathrm{R}$ & 27 & .975 \\
\hline
\end{tabular}


Table 4. Correlation coefficients of annual peak streamflows for paired stations in south Texas basins [USGS, U.S. Geological Survey; R, regulated; U, unregulated]

\begin{tabular}{|c|c|c|c|c|c|}
\hline $\begin{array}{l}\text { Station } \\
\text { pair no. } \\
\text { (fig. 13) }\end{array}$ & $\begin{array}{c}\text { USGS } \\
\text { upstream } \\
\text { station no. }\end{array}$ & $\begin{array}{c}\text { USGS } \\
\text { downstream } \\
\text { station no. }\end{array}$ & $\begin{array}{l}\text { Basin } \\
\text { regulation } \\
\text { condition }\end{array}$ & $\begin{array}{c}\text { Common years } \\
\text { of record }\end{array}$ & $\begin{array}{l}\text { Correlation } \\
\text { coefficient }\end{array}$ \\
\hline 1 & 08120700 & 08121000 & $\mathrm{R}$ & 31 & 0.923 \\
\hline 2 & 08123800 & 08123850 & $\mathrm{R}$ & 29 & .621 \\
\hline 3 & 08123850 & 08124000 & $\mathrm{R}$ & 28 & .382 \\
\hline 4 & 08124000 & 08126380 & $\mathrm{R}$ & 17 & .439 \\
\hline 5 & 08126380 & 08136700 & $\mathrm{R}$ & 17 & .794 \\
\hline 6 & 08136700 & 08138000 & $\mathrm{R}$ & 27 & .682 \\
\hline 7 & 08138000 & 08147000 & $\mathrm{R}$ & 68 & .755 \\
\hline 8 & 08133500 & 08134000 & $\mathrm{R}$ & 56 & .737 \\
\hline 9 & 08136000 & 08136500 & $\mathrm{R}$ & 82 & .828 \\
\hline 10 & 08144500 & 08144600 & $\mathrm{R}$ & 16 & .764 \\
\hline 11 & 08150800 & 08151500 & $\mathrm{R}$ & 33 & .269 \\
\hline 12 & 08158000 & 08159200 & $\mathrm{R}$ & 36 & .853 \\
\hline 13 & 08159200 & 08160400 & $\mathrm{R}$ & 8 & .940 \\
\hline 14 & 08161000 & 08162000 & $\mathrm{R}$ & 66 & .977 \\
\hline 15 & 08162000 & 08162500 & $\mathrm{R}$ & 49 & .964 \\
\hline 16 & 08163500 & 08164000 & $\mathrm{U}$ & 57 & .700 \\
\hline 17 & 08165300 & 08165500 & $\mathrm{U}$ & 30 & .932 \\
\hline 18 & 08165500 & 08166200 & $\mathrm{U}$ & 12 & .976 \\
\hline 19 & 08166200 & 08167000 & $\mathrm{U}$ & 12 & .928 \\
\hline 20 & 08167000 & 08167500 & $\mathrm{U}$ & 67 & .854 \\
\hline 21 & 08167800 & 08168500 & $\mathrm{R}$ & 37 & .724 \\
\hline 22 & 08168500 & 08169500 & $\mathrm{R}$ & 19 & .943 \\
\hline 23 & 08171000 & 08171300 & $\mathrm{R}$ & 42 & .904 \\
\hline 24 & 08171300 & 08172000 & $\mathrm{R}$ & 28 & .721 \\
\hline 25 & 08173900 & 08175800 & $\mathrm{R}$ & 12 & .880 \\
\hline 26 & 08175800 & 08176500 & $\mathrm{R}$ & 33 & .970 \\
\hline 27 & 08183900 & 08185000 & $\mathrm{R}$ & 30 & .440 \\
\hline 28 & 08185000 & 08186000 & $\mathrm{R}$ & 35 & .519 \\
\hline 29 & 08178000 & 08178050 & $\mathrm{R}$ & 4 & .941 \\
\hline 30 & 08180700 & 08180800 & $\mathrm{R}$ & 14 & .928 \\
\hline 31 & 08180800 & 08181500 & $\mathrm{R}$ & 25 & .944 \\
\hline
\end{tabular}


Table 4. Correlation coefficients of annual peak streamflows for paired stations in south Texas basins-Continued

\begin{tabular}{cccccc}
\hline $\begin{array}{c}\text { Station } \\
\text { pair no. } \\
\text { (fig. 13) }\end{array}$ & $\begin{array}{c}\text { USGS } \\
\text { upstream } \\
\text { station no. }\end{array}$ & $\begin{array}{c}\text { USGS } \\
\text { downstream } \\
\text { station no. }\end{array}$ & $\begin{array}{c}\text { Basin } \\
\text { regulation } \\
\text { condition }\end{array}$ & $\begin{array}{c}\text { Common years } \\
\text { of record }\end{array}$ & $\begin{array}{c}\text { Correlation } \\
\text { coefficient }\end{array}$ \\
\hline 32 & 08181500 & 08181800 & $\mathrm{R}$ & 34 & 0.903 \\
33 & 08181800 & 08183500 & $\mathrm{R}$ & 34 & .879 \\
34 & 08183500 & 08188500 & $\mathrm{R}$ & 63 & .743 \\
35 & 08190500 & 08192000 & $\mathrm{U}$ & 52 & .696 \\
36 & 08190000 & 08192000 & $\mathrm{U}$ & 69 & .906 \\
37 & 08193000 & 08194000 & $\mathrm{R}$ & 57 & .754 \\
38 & 08194000 & 08194500 & $\mathrm{R}$ & 55 & .747 \\
39 & 08194500 & 08210000 & $\mathrm{R}$ & 17 & .899 \\
40 & 08196000 & 08197500 & $\mathrm{R}$ & 44 & .793 \\
41 & 08195000 & 08197500 & $\mathrm{R}$ & 45 & .860 \\
42 & 08197500 & 08205500 & $\mathrm{R}$ & 45 & .509 \\
43 & 08205500 & 08206600 & $\mathrm{R}$ & 18 & .816 \\
44 & 08198000 & 08198500 & $\mathrm{R}$ & 44 & .863 \\
45 & 08201500 & 08202700 & $\mathrm{R}$ & 35 & .361 \\
46 & 08200000 & 08200700 & $\mathrm{R}$ & 36 & .782 \\
47 & 08208000 & 08210000 & $\mathrm{R}$ & 56 & .751 \\
48 & 08210000 & 08211000 & $\mathrm{R}$ & 13 & .851 \\
49 & 08412500 & 08446500 & $\mathrm{R}$ & 56 & \\
\hline
\end{tabular}


[USGS, U.S. Geological Survey; major objective 1, regionalization; major objective 2, major flow; major objective 3, outflow from State; major objective 4, streamflow condition assessment; D, discontinued; CR, continuous-record station; R, regulated; --, objective not met; A, active; U, unregulated; PR partial-record station]

\section{USGS}

station

no.

(pl. 1)

07227448 Punta de Agua Creek near Channing, Tex.

07227500 Canadian River near Amarillo, Tex.

${ }^{2} 07228000$ Canadian River near Canadian, Tex.

07233500 Palo Duro Creek near Spearman, Tex.

07235000 Wolf Creek at Lipscomb, Tex.

${ }^{2} 07297910$ Prairie Dog Town Fork Red River near Wayside, Tex.

07298000 North Tule Draw at reservoir near Tulia, Tex.

07298500 Prairie Dog Town Fork Red River near Brice, Tex.

${ }^{3} 07299512$ Jonah Creek at Weir near Estelline, Tex.

07299540 Prairie Dog Town Fork Red River near Childress, Tex.

07299670 Groesbeck Creek at State Hwy. 6 near Quanah, Tex.

07299890 Lelia Lake Creek below Bell Creek near Hedley, Tex.

${ }^{2} 07300000$ Salt Fork Red River near Wellington, Tex.

07301410 Sweetwater Creek near Kelton, Tex.

${ }^{2} 07308200$ Pease River near Vernon, Tex.

07308500 Red River near Burkburnett, Tex.

07311630 Middle Wichita River near Guthrie, Tex.

07311700 North Wichita River near Truscott, Tex.

07311800 South Wichita River near Benjamin, Tex.

07311900 Wichita River near Seymour, Tex.

07312500 Wichita River at Wichita Falls, Tex.

07314500 Little Wichita River near Archer City, Tex.

07314900 Little Wichita River above Henrietta, Tex.

07315200 East Fork Little Wichita River near Henrietta, Tex.

${ }^{3} 07316000$ Red River near Gainesville, Tex.

07316200 Mineral Creek near Sadler, Tex.

${ }^{3} 07336750$ Little Pine Creek near Kanawha, Tex.

07337000 Red River at Index, Ark.

Footnotes at end of table.

\begin{tabular}{|c|c|c|c|c|c|c|c|c|c|}
\hline \multirow{2}{*}{$\begin{array}{c}\text { Status } \\
\text { as of } \\
10 / 01 / 99\end{array}$} & \multirow{2}{*}{$\begin{array}{c}\text { Type } \\
\text { of } \\
\text { data }\end{array}$} & \multirow{2}{*}{$\begin{array}{l}\text { Record } \\
\text { length } \\
\text { (water } \\
\text { years }{ }^{1} \text { ) }\end{array}$} & \multirow{2}{*}{$\begin{array}{c}\text { Regulation } \\
\text { condition } \\
\text { through } \\
1997\end{array}$} & \multirow{2}{*}{$\begin{array}{l}\text { Drainage } \\
\text { area } \\
\text { (square } \\
\text { miles) }\end{array}$} & \multirow{2}{*}{$\begin{array}{l}\text { Hydrologic } \\
\text { region } \\
\text { (fig. 3) }\end{array}$} & \multicolumn{4}{|c|}{$\begin{array}{c}\text { Major objective } \\
\text { of core } \\
\text { network met }\end{array}$} \\
\hline & & & & & & 1 & 2 & 3 & 4 \\
\hline D & CR & 6 & $\mathrm{R}$ & 3,570 & 1 & $\sqrt{ }$ & $\sqrt{ }$ & - & -- \\
\hline A & $\mathrm{CR}$ & 65 & $\mathrm{R}$ & 15,400 & 1 & -- & $\checkmark$ & -- & $\checkmark$ \\
\hline A & $\mathrm{CR}$ & 63 & $\mathrm{R}$ & 18,200 & 1 & -- & $\checkmark$ & $\sqrt{ }$ & -- \\
\hline A & $\mathrm{CR}$ & 37 & $\mathrm{U}$ & 440 & 1 & $\sqrt{ }$ & -- & -- & -- \\
\hline A & $\mathrm{CR}$ & 44 & $\mathrm{R}$ & 475 & 1 & -- & -- & -- & $\checkmark$ \\
\hline A & $\mathrm{CR}$ & 33 & $\mathrm{U}$ & 930 & 1 & $\checkmark$ & -- & -- & $\checkmark$ \\
\hline D & $\mathrm{CR}$ & 31 & $\mathrm{U}$ & 65.0 & 1 & $\checkmark$ & -- & -- & -- \\
\hline D & $\mathrm{CR}$ & 11 & $\mathrm{U}$ & 1,580 & 1 & $\sqrt{ }$ & $\checkmark$ & -- & -- \\
\hline D & $\mathrm{CR}$ & 8 & $\mathrm{U}$ & 65.5 & 1 & $\sqrt{ }$ & -- & -- & -- \\
\hline A & $\mathrm{CR}$ & 36 & $\mathrm{R}$ & 2,960 & 1 & $\checkmark$ & $\checkmark$ & -- & -- \\
\hline A & $\mathrm{CR}$ & 39 & $\mathrm{U}$ & 303 & 3 & $\sqrt{ }$ & -- & -- & -- \\
\hline A & $\mathrm{CR}$ & 3 & $\mathrm{U}$ & 74.0 & 1 & $\checkmark$ & -- & -- & -- \\
\hline A & $\mathrm{CR}$ & 48 & $\mathrm{U}$ & 1,010 & 1 & $\sqrt{ }$ & $\checkmark$ & $\sqrt{ }$ & $\checkmark$ \\
\hline A & $\mathrm{CR}$ & 38 & $\mathrm{U}$ & 267 & 1 & $\checkmark$ & -- & -- & -- \\
\hline A & $\mathrm{CR}$ & 39 & $\mathrm{U}$ & 2,930 & 3 & $\sqrt{ }$ & $\checkmark$ & -- & $\checkmark$ \\
\hline A & $\mathrm{CR}$ & 41 & $\mathrm{U}$ & 14,600 & 3 & $\sqrt{ }$ & $\checkmark$ & -- & -- \\
\hline A & $\mathrm{CR}$ & 4 & $\mathrm{U}$ & 50.3 & 3 & $\sqrt{ }$ & -- & -- & -- \\
\hline A & $\mathrm{CR}$ & 40 & $\mathrm{U}$ & 937 & 3 & $\checkmark$ & -- & -- & -- \\
\hline A & $\mathrm{CR}$ & 40 & $\mathrm{U}$ & 584 & 3 & $\checkmark$ & -- & -- & -- \\
\hline A & $\mathrm{CR}$ & 21 & $\mathrm{U}$ & 1,870 & 3 & $\sqrt{ }$ & $\checkmark$ & -- & -- \\
\hline A & $\mathrm{CR}$ & 63 & $\mathrm{R}$ & 3,140 & 3 & -- & $\checkmark$ & -- & -- \\
\hline A & $\mathrm{CR}$ & 59 & $\mathrm{R}$ & 481 & 3 & -- & -- & -- & $\checkmark$ \\
\hline A & $\mathrm{CR}$ & 47 & $\mathrm{R}$ & 1,040 & 3 & -- & $\checkmark$ & -- & -- \\
\hline A & $\mathrm{CR}$ & 37 & $\mathrm{U}$ & 178 & 3 & $\checkmark$ & -- & -- & -- \\
\hline A & $\mathrm{CR}$ & 65 & $\mathrm{R}$ & 24,800 & 7 & -- & $\checkmark$ & -- & -- \\
\hline D & $\mathrm{CR}$ & 8 & $\mathrm{U}$ & 26.0 & 7 & $\sqrt{ }$ & -- & -- & -- \\
\hline D & $\mathrm{CR}$ & 12 & $\mathrm{U}$ & 75.4 & 10 & $\checkmark$ & -- & -- & -- \\
\hline A & $\mathrm{CR}$ & 64 & $\mathrm{R}$ & 42,094 & 10 & -- & $\checkmark$ & $\checkmark$ & -- \\
\hline
\end{tabular}


Table 5. Core network of streamflow-gaging stations in Texas-Continued

\begin{tabular}{|c|c|c|c|c|c|c|c|c|c|c|c|}
\hline \multirow{2}{*}{$\begin{array}{c}\text { USGS } \\
\text { station } \\
\text { no. } \\
\text { (pl. 1) }\end{array}$} & \multirow[t]{2}{*}{ Name } & \multirow{2}{*}{$\begin{array}{c}\text { Status } \\
\text { as of } \\
10 / 01 / 99\end{array}$} & \multirow{2}{*}{$\begin{array}{l}\text { Type } \\
\text { of } \\
\text { data }\end{array}$} & \multirow{2}{*}{$\begin{array}{l}\text { Record } \\
\text { length } \\
\text { (water } \\
\text { years }^{1} \text { ) }\end{array}$} & \multirow{2}{*}{$\begin{array}{c}\text { Regulation } \\
\text { condition } \\
\text { through } \\
1997\end{array}$} & \multirow{2}{*}{$\begin{array}{l}\text { Drainage } \\
\text { area } \\
\text { (square } \\
\text { miles) }\end{array}$} & \multirow{2}{*}{$\begin{array}{l}\text { Hydrologic } \\
\text { region } \\
\text { (fig. 3) }\end{array}$} & \multicolumn{4}{|c|}{$\begin{array}{c}\text { Major objective } \\
\text { of core } \\
\text { network met }\end{array}$} \\
\hline & & & & & & & & 1 & 2 & 3 & 4 \\
\hline 07342465 & South Sulphur River at Commerce, Tex. & $\mathrm{A}$ & $\mathrm{CR}$ & 9 & $\mathrm{U}$ & 150 & 7 & $\sqrt{ }$ & -- & -- & -- \\
\hline 07342480 & Middle Sulphur River at Commerce, Tex. & A & $\mathrm{CR}$ & 9 & $\mathrm{U}$ & 44.1 & 7 & $\sqrt{ }$ & -- & -- & -- \\
\hline${ }^{2} 07343000$ & North Sulphur River near Cooper, Tex. & A & $\mathrm{CR}$ & 51 & $\mathrm{U}$ & 276 & 10 & $\checkmark$ & -- & -- & $\checkmark$ \\
\hline 07343200 & Sulphur River near Talco, Tex. & $\mathrm{D}$ & $\mathrm{CR}$ & 41 & $\mathrm{R}$ & 1,370 & 10 & -- & $\sqrt{ }$ & -- & -- \\
\hline${ }^{2} 07343500$ & White Oak Creek near Talco, Tex. & A & $\mathrm{CR}$ & 51 & $\mathrm{R}$ & 494 & 10 & -- & -- & -- & $\sqrt{ }$ \\
\hline 07344486 & Brushy Creek at Scroggins, Tex. & A & $\mathrm{CR}$ & 22 & $\mathrm{U}$ & 23.4 & 10 & $\checkmark$ & -- & -- & -- \\
\hline 07346000 & Big Cypress Creek near Jefferson, Tex. & A & $\mathrm{CR}$ & 56 & $\mathrm{R}$ & 850 & 10 & -- & -- & $\sqrt{ }$ & -- \\
\hline 07346045 & Black Cypress Bayou at Jefferson, Tex. & A & $\mathrm{CR}$ & 32 & $\mathrm{U}$ & 365 & 10 & $\sqrt{ }$ & -- & $\sqrt{ }$ & -- \\
\hline${ }^{2} 07346070$ & Little Cypress Creek near Jefferson, Tex. & A & $\mathrm{CR}$ & 55 & $\mathrm{U}$ & 675 & 10 & $\checkmark$ & -- & $\sqrt{ }$ & $\checkmark$ \\
\hline 08017200 & Cowleech Fork Sabine River at Greenville, Tex. & A & $\mathrm{CR}$ & 42 & $\mathrm{U}$ & 77.7 & 7 & $\sqrt{ }$ & -- & -- & -- \\
\hline${ }^{2} 08017300$ & South Fork Sabine River near Quinlan, Tex. & A & $\mathrm{CR}$ & 42 & $\mathrm{U}$ & 78.7 & 7 & $\sqrt{ }$ & -- & -- & -- \\
\hline 08018500 & Sabine River near Mineola, Tex. & A & $\mathrm{CR}$ & 55 & $\mathrm{R}$ & 1,360 & 10 & -- & $\sqrt{ }$ & -- & -- \\
\hline 08018730 & Burke Creek near Yantis, Tex. & $\mathrm{D}$ & $\mathrm{CR}$ & 10 & $\mathrm{U}$ & 33.1 & 10 & $\checkmark$ & -- & -- & -- \\
\hline 08020000 & Sabine River near Gladewater, Tex. & A & $\mathrm{CR}$ & 69 & $\mathrm{R}$ & 2,790 & 10 & -- & $\sqrt{ }$ & -- & -- \\
\hline 08020200 & Prairie Creek near Gladewater, Tex. & $\mathrm{D}$ & $\mathrm{CR}$ & 9 & $\mathrm{U}$ & 48.9 & 10 & $\checkmark$ & -- & -- & -- \\
\hline${ }^{3} 08021000$ & Cherokee Bayou near Elderville, Tex. & $\mathrm{D}$ & $\mathrm{CR}$ & 9 & $\mathrm{U}$ & 120 & 10 & $\checkmark$ & -- & -- & -- \\
\hline 08022040 & Sabine River near Beckville, Tex. & A & $\mathrm{CR}$ & 62 & $\mathrm{R}$ & 3,590 & 10 & -- & $\checkmark$ & $\sqrt{ }$ & $\sqrt{ }$ \\
\hline${ }^{3} 08022400$ & Socagee Creek near Carthage, Tex. & $\mathrm{D}$ & $\mathrm{CR}$ & 12 & $\mathrm{U}$ & 82.6 & 10 & $\sqrt{ }$ & -- & -- & -- \\
\hline 08026000 & Sabine River near Burkeville, Tex. & A & $\mathrm{CR}$ & 45 & $\mathrm{R}$ & 7,480 & 11 & $\checkmark$ & $\checkmark$ & -- & -- \\
\hline 08029500 & Big Cow Creek near Newton, Tex. & A & $\mathrm{CR}$ & 49 & $\mathrm{U}$ & 128 & 11 & $\sqrt{ }$ & -- & -- & $\sqrt{ }$ \\
\hline${ }^{2} 08030500$ & Sabine River near Ruliff, Tex. & A & $\mathrm{CR}$ & 76 & $\mathrm{R}$ & 9,330 & 11 & -- & $\sqrt{ }$ & $\sqrt{ }$ & -- \\
\hline 08032000 & Neches River near Neches, Tex. & A & $\mathrm{CR}$ & 62 & $\mathrm{R}$ & 1,150 & 10 & -- & $\sqrt{ }$ & -- & -- \\
\hline 08033500 & Neches River near Rockland, Tex. & A & $\mathrm{CR}$ & 95 & $\mathrm{R}$ & 3,640 & 11 & -- & $\checkmark$ & -- & $\sqrt{ }$ \\
\hline${ }^{3} 08033700$ & Striker Creek near Summerfield, Tex. & $\mathrm{D}$ & $\mathrm{CR}$ & 9 & $\mathrm{U}$ & 146 & 10 & $\sqrt{ }$ & -- & -- & -- \\
\hline 08036500 & Angelina River near Alto, Tex. & A & $\mathrm{CR}$ & 43 & $\mathrm{R}$ & 1,280 & 10 & -- & $\checkmark$ & -- & $\sqrt{ }$ \\
\hline${ }^{2} 08041000$ & Neches River at Evadale, Tex. & A & $\mathrm{CR}$ & 82 & $\mathrm{R}$ & 7,950 & 11 & -- & $\checkmark$ & $\sqrt{ }$ & -- \\
\hline${ }^{2} 08041500$ & Village Creek near Kountze, Tex. & A & $\mathrm{CR}$ & 65 & $\mathrm{U}$ & 860 & 11 & $\checkmark$ & -- & $\sqrt{ }$ & $\checkmark$ \\
\hline 08041700 & Pine Island Bayou near Sour Lake, Tex. & A & $\mathrm{CR}$ & 33 & $\mathrm{U}$ & 336 & 11 & $\checkmark$ & -- & $\sqrt{ }$ & -- \\
\hline 08044500 & West Fork Trinity River near Boyd, Tex. & A & $\mathrm{CR}$ & 53 & $\mathrm{U}$ & 1,730 & 7 & $\checkmark$ & $\checkmark$ & -- & -- \\
\hline 08044800 & Walnut Creek at Reno, Tex. & A & $\mathrm{CR}$ & 8 & $\mathrm{U}$ & 75.6 & 7 & $\sqrt{ }$ & -- & -- & -- \\
\hline
\end{tabular}


Table 5. Core network of streamflow-gaging stations in Texas-Continued

\begin{tabular}{|c|c|c|c|c|c|c|c|c|c|c|c|}
\hline \multirow{2}{*}{$\begin{array}{c}\text { USGS } \\
\text { station } \\
\text { no. } \\
\text { (pl. 1) }\end{array}$} & \multirow[t]{2}{*}{ Name } & \multirow[t]{2}{*}{$\begin{array}{l}\text { Status } \\
\text { as of } \\
10 / 01 / 99\end{array}$} & \multirow[t]{2}{*}{$\begin{array}{l}\text { Type } \\
\text { of } \\
\text { data }\end{array}$} & \multirow{2}{*}{$\begin{array}{l}\text { Record } \\
\text { length } \\
\text { (water } \\
\text { years }^{1} \text { ) }\end{array}$} & \multirow{2}{*}{$\begin{array}{c}\text { Regulation } \\
\text { condition } \\
\text { through } \\
1997\end{array}$} & \multirow{2}{*}{$\begin{array}{l}\text { Drainage } \\
\text { area } \\
\text { (square } \\
\text { miles) }\end{array}$} & \multirow{2}{*}{$\begin{array}{l}\text { Hydrologic } \\
\text { region } \\
\text { (fig. 3) }\end{array}$} & \multicolumn{4}{|c|}{$\begin{array}{c}\text { Major objective } \\
\text { of core } \\
\text { network met }\end{array}$} \\
\hline & & & & & & & & 1 & 2 & 3 & 4 \\
\hline${ }^{3} 08046000$ & Clear Fork Trinity River near Aledo, Tex. & $\mathrm{D}$ & $\mathrm{CR}$ & 28 & $\mathrm{R}$ & 251 & 7 & $\sqrt{ }$ & -- & -- & - \\
\hline 08048000 & West Fork Trinity River at Fort Worth, Tex. & A & $\mathrm{CR}$ & 80 & $\mathrm{R}$ & 2,620 & 7 & -- & $\checkmark$ & -- & - \\
\hline 08048970 & Village Creek at Everman, Tex. & A & $\mathrm{CR}$ & 11 & $\mathrm{U}$ & 84.5 & 7 & $\sqrt{ }$ & -- & -- & - \\
\hline 08049500 & West Fork Trinity River at Grand Prairie, Tex. & A & $\mathrm{CR}$ & 76 & $\mathrm{R}$ & 3,070 & 7 & -- & $\checkmark$ & -- & - \\
\hline${ }^{3} 08049550$ & Big Bear Creek near Grapevine, Tex. & $\mathrm{D}$ & $\mathrm{CR}$ & 13 & $\mathrm{U}$ & 29.6 & 7 & $\checkmark$ & -- & -- & - \\
\hline 08049580 & Mountain Creek near Venus, Tex. & A & PR & 14 & $\mathrm{U}$ & 25.5 & 7 & $\sqrt{ }$ & -- & -- & - \\
\hline 08049700 & Walnut Creek near Mansfield, Tex. & A & $\mathrm{CR}$ & 40 & $\mathrm{U}$ & 62.8 & 7 & $\sqrt{ }$ & -- & -- & - \\
\hline 08050400 & Elm Fork Trinity River at Gainesville, Tex. & A & $\mathrm{CR}$ & 15 & $\mathrm{U}$ & 174 & 7 & $\sqrt{ }$ & -- & -- & - \\
\hline 08050800 & Timber Creek near Collinsville, Tex. & A & $\mathrm{CR}$ & 15 & $\mathrm{U}$ & 38.8 & 7 & $\sqrt{ }$ & -- & -- & - \\
\hline 08050840 & Range Creek near Collinsville, Tex. & A & $\mathrm{CR}$ & 8 & $\mathrm{U}$ & 29.2 & 7 & $\sqrt{ }$ & -- & -- & - \\
\hline 08052700 & Little Elm Creek near Aubrey, Tex. & A & $\mathrm{CR}$ & 41 & $\mathrm{R}$ & 75.5 & 7 & $\sqrt{ }$ & -- & -- & - \\
\hline${ }^{2} 08053500$ & Denton Creek near Justin, Tex. & A & $\mathrm{CR}$ & 51 & $\mathrm{R}$ & 400 & 7 & -- & -- & -- & $\sqrt{ }$ \\
\hline 08055500 & Elm Fork Trinity River near Carrollton, Tex. & $\mathrm{A}$ & $\mathrm{CR}$ & 77 & $\mathrm{R}$ & 2,460 & 7 & -- & $\checkmark$ & -- & -- \\
\hline${ }^{3} 08056500$ & Turtle Creek at Dallas, Tex. & $\mathrm{D}$ & $\mathrm{CR}$ & 41 & $\mathrm{R}$ & 7.98 & 7 & $\sqrt{ }$ & -- & -- & -- \\
\hline 08057410 & Trinity River below Dallas, Tex. & A & $\mathrm{CR}$ & 44 & $\mathrm{R}$ & 6,280 & 7 & -- & $\checkmark$ & -- & -- \\
\hline 08061540 & Rowlett Creek near Sachse, Tex. & A & $\mathrm{CR}$ & 31 & $\mathrm{U}$ & 120 & 7 & $\sqrt{ }$ & -- & -- & - \\
\hline 08062000 & East Fork Trinity River near Crandall, Tex. & A & $\mathrm{CR}$ & 50 & $\mathrm{R}$ & 1,260 & 7 & -- & $\sqrt{ }$ & -- & - \\
\hline 08062500 & Trinity River near Rosser, Tex. & A & $\mathrm{CR}$ & 63 & $\mathrm{R}$ & 8146 & 7 & -- & $\sqrt{ }$ & -- & -- \\
\hline${ }^{3} 08062900$ & Kings Creek near Kaufman, Tex. & $\mathrm{D}$ & $\mathrm{CR}$ & 25 & $\mathrm{R}$ & 233 & 7 & $\sqrt{ }$ & -- & -- & - \\
\hline 08064100 & Chambers Creek near Rice, Tex. & A & $\mathrm{CR}$ & 17 & $\mathrm{R}$ & 807 & 7 & -- & -- & -- & $\sqrt{ }$ \\
\hline 08064700 & Tehuacana Creek near Streetman, Tex. & A & $\mathrm{CR}$ & 32 & $\mathrm{U}$ & 142 & 7 & $\sqrt{ }$ & -- & -- & - \\
\hline 08065000 & Trinity River near Oakwood, Tex. & A & $\mathrm{CR}$ & 77 & $\mathrm{R}$ & 12,800 & 7 & -- & $\sqrt{ }$ & -- & - \\
\hline 08065200 & Upper Keechi Creek near Oakwood, Tex. & A & $\mathrm{CR}$ & 39 & $\mathrm{U}$ & 150 & 7 & $\sqrt{ }$ & -- & -- & - \\
\hline 08065700 & Caney Creek near Madisonville, Tex. & $\mathrm{D}$ & $\mathrm{CR}$ & 13 & $\mathrm{U}$ & 112 & 8 & $\sqrt{ }$ & -- & -- & - \\
\hline${ }^{2} 08065800$ & Bedias Creek near Madisonville, Tex. & A & $\mathrm{CR}$ & 33 & $\mathrm{U}$ & 321 & 8 & $\sqrt{ }$ & -- & -- & $\sqrt{ }$ \\
\hline 08066170 & Kickapoo Creek near Onalaska, Tex. & A & $\mathrm{CR}$ & 35 & $\mathrm{U}$ & 57.0 & 11 & $\sqrt{ }$ & -- & -- & - \\
\hline 08066200 & Long King Creek at Livingston, Tex. & A & $\mathrm{CR}$ & 38 & $\mathrm{U}$ & 141 & 11 & $\sqrt{ }$ & -- & -- & - \\
\hline 08066300 & Menard Creek near Rye, Tex. & A & $\mathrm{CR}$ & 35 & $\mathrm{U}$ & 152 & 11 & $\checkmark$ & -- & -- & $\sqrt{ }$ \\
\hline${ }^{2} 08066500$ & Trinity River at Romayer, Tex. & A & $\mathrm{CR}$ & 77 & $\mathrm{R}$ & 17,200 & 11 & -- & $\sqrt{ }$ & $\sqrt{ }$ & - \\
\hline 08067500 & Cedar Bayou near Crosby, Tex. & A & PR & 29 & $\mathrm{U}$ & 64.9 & 11 & $\sqrt{ }$ & -- & -- & -- \\
\hline
\end{tabular}


Table 5. Core network of streamflow-gaging stations in Texas-Continued

\begin{tabular}{|c|c|c|c|c|c|c|c|c|c|c|c|}
\hline \multirow{2}{*}{$\begin{array}{c}\text { USGS } \\
\text { station } \\
\text { no. } \\
\text { (pl. 1) }\end{array}$} & \multirow[t]{2}{*}{ Name } & \multirow{2}{*}{$\begin{array}{l}\text { Status } \\
\text { as of } \\
10 / 01 / 99\end{array}$} & \multirow{2}{*}{$\begin{array}{l}\text { Type } \\
\text { of } \\
\text { data }\end{array}$} & \multirow{2}{*}{$\begin{array}{l}\text { Record } \\
\text { length } \\
\text { (water } \\
\text { years }^{1} \text { ) }\end{array}$} & \multirow{2}{*}{$\begin{array}{c}\text { Regulation } \\
\text { condition } \\
\text { through } \\
1997\end{array}$} & \multirow{2}{*}{$\begin{array}{l}\text { Drainage } \\
\text { area } \\
\text { (square } \\
\text { miles) }\end{array}$} & \multirow{2}{*}{$\begin{array}{l}\text { Hydrologic } \\
\text { region } \\
\text { (fig. } 3 \text { ) }\end{array}$} & \multicolumn{4}{|c|}{$\begin{array}{l}\text { Major objective } \\
\text { of core } \\
\text { network met }\end{array}$} \\
\hline & & & & & & & & 1 & 2 & 3 & 4 \\
\hline 08068450 & Panther Branch near Spring, Tex. & $\mathrm{D}$ & $\mathrm{CR}$ & 6 & $\mathrm{U}$ & 34.5 & 11 & $\sqrt{ }$ & -- & -- & -- \\
\hline${ }^{2} 08068500$ & Spring Creek near Spring, Tex. & A & $\mathrm{CR}$ & 62 & $\mathrm{U}$ & 409 & 11 & $\checkmark$ & -- & -- & $\checkmark$ \\
\hline 08068780 & Little Cypress Creek near Cypress, Tex. & A & PR & 18 & $\mathrm{U}$ & 41.0 & 11 & $\checkmark$ & -- & -- & -- \\
\hline 08069000 & Cypress Creek near Westfield, Tex. & A & $\mathrm{CR}$ & 56 & $\mathrm{U}$ & 285 & 11 & $\checkmark$ & -- & -- & -- \\
\hline${ }^{2} 08070000$ & East Fork San Jacinto River near Cleveland, Tex. & A & $\mathrm{CR}$ & 61 & $\mathrm{U}$ & 325 & 11 & $\sqrt{ }$ & -- & -- & $\checkmark$ \\
\hline 08070500 & Caney Creek near Splendora, Tex. & A & $\mathrm{CR}$ & 57 & $\mathrm{U}$ & 105 & 11 & $\sqrt{ }$ & -- & -- & -- \\
\hline${ }^{4} 08071000$ & Peach Creek at Splendora, Tex. & A & $\mathrm{CR}$ & 36 & $\mathrm{U}$ & 117 & 11 & $\checkmark$ & -- & -- & -- \\
\hline 08071280 & Luce Bayou above Lake Houston, near Huffman, Tex. & A & $\mathrm{CR}$ & 16 & $\mathrm{U}$ & 218 & 11 & $\sqrt{ }$ & -- & -- & -- \\
\hline${ }^{4} 08072050$ & San Jacinto River near Sheldon, Tex. & A & PR & 31 & $\mathrm{U}$ & 2,880 & 11 & -- & $\checkmark$ & $\sqrt{ }$ & -- \\
\hline 08072300 & Buffalo Bayou near Katy, Tex. & A & $\mathrm{CR}$ & 23 & $\mathrm{U}$ & 63.3 & 11 & $\checkmark$ & -- & -- & -- \\
\hline 08072730 & Bear Creek near Barker, Tex. & A & $\mathrm{CR}$ & 23 & $\mathrm{U}$ & 21.5 & 11 & $\sqrt{ }$ & -- & -- & -- \\
\hline${ }^{3} 08072760$ & Langham Creek at West Little York Rd. near Addicks, Tex. & A & PR & 23 & $\mathrm{U}$ & 24.6 & 11 & $\checkmark$ & -- & -- & -- \\
\hline 08076180 & Garners Bayou near Humble, Tex. & A & PR & 14 & $\mathrm{U}$ & 31.0 & 11 & $\sqrt{ }$ & -- & -- & -- \\
\hline 08078000 & Chocolate Bayou near Alvin, Tex. & A & $\mathrm{CR}$ & 54 & $\mathrm{U}$ & 87.7 & 11 & $\sqrt{ }$ & -- & -- & -- \\
\hline${ }^{3} 08079500$ & North Fork Double Mountain Fork Brazos River at Lubbock, Tex. & $\mathrm{D}$ & $\mathrm{CR}$ & 12 & $\mathrm{U}$ & 200 & 1 & $\checkmark$ & -- & -- & -- \\
\hline 08079600 & Double Mountain Fork Brazos River at Justiceburg, Tex. & A & $\mathrm{CR}$ & 39 & $\mathrm{U}$ & 244 & 3 & $\checkmark$ & -- & -- & -- \\
\hline${ }^{2} 08080500$ & Double Mountain Fork Brazos River near Aspermont, Tex. & A & $\mathrm{CR}$ & 72 & $\mathrm{U}$ & 1,860 & 3 & $\checkmark$ & $\checkmark$ & -- & $\checkmark$ \\
\hline${ }^{3} 08080540$ & McDonald Creek near Post, Tex. & $\mathrm{D}$ & $\mathrm{CR}$ & 13 & $\mathrm{U}$ & 79.2 & 3 & $\checkmark$ & -- & -- & -- \\
\hline 08082000 & Salt Fork Brazos River near Aspermont, Tex. & A & $\mathrm{CR}$ & 64 & $\mathrm{R}$ & 2,500 & 3 & -- & $\checkmark$ & -- & -- \\
\hline 08082500 & Brazos River at Seymour, Tex. & A & $\mathrm{CR}$ & 77 & $\mathrm{R}$ & 5,970 & 3 & -- & $\checkmark$ & -- & -- \\
\hline 08082700 & Millers Creek near Munday, Tex. & A & $\mathrm{CR}$ & 37 & $\mathrm{U}$ & 104 & 3 & $\sqrt{ }$ & -- & -- & -- \\
\hline 08083100 & Clear Fork Brazos River near Roby, Tex. & A & $\mathrm{CR}$ & 38 & $\mathrm{U}$ & 228 & 3 & $\sqrt{ }$ & -- & -- & -- \\
\hline${ }^{3} 08083400$ & Little Elm Creek near Abilene, Tex. & $\mathrm{D}$ & $\mathrm{CR}$ & 16 & $\mathrm{U}$ & 39.1 & 3 & $\checkmark$ & -- & -- & -- \\
\hline 08083420 & Cat Claw Creek at Abilene, Tex. & A & PR & 11 & $\mathrm{U}$ & 13.0 & 3 & $\sqrt{ }$ & -- & -- & -- \\
\hline 08083480 & Cedar Creek at I-20 at Abilene, Tex. & A & PR & 7 & $\mathrm{U}$ & 136 & 3 & $\checkmark$ & -- & -- & -- \\
\hline 08084000 & Clear Fork Brazos River at Nugent, Tex. & A & $\mathrm{CR}$ & 77 & $\mathrm{R}$ & 2,200 & 3 & -- & $\checkmark$ & -- & -- \\
\hline 08084800 & California Creek near Stamford, Tex. & A & $\mathrm{CR}$ & 38 & $\mathrm{U}$ & 478 & 3 & $\sqrt{ }$ & -- & -- & -- \\
\hline 08085500 & Clear Fork Brazos River at Fort Griffin, Tex. & A & $\mathrm{CR}$ & 77 & $\mathrm{R}$ & 3,990 & 3 & -- & $\checkmark$ & -- & -- \\
\hline${ }^{3} 08086050$ & Deep Creek at Moran, Tex. & $\mathrm{D}$ & $\mathrm{CR}$ & 15 & $\mathrm{U}$ & 228 & 3 & $\checkmark$ & -- & -- & -- \\
\hline${ }^{2} 08086212$ & Hubbard Creek below Albany, Tex. & A & $\mathrm{CR}$ & 34 & $\mathrm{U}$ & 613 & 3 & $\checkmark$ & -- & -- & $\sqrt{ }$ \\
\hline
\end{tabular}


Table 5. Core network of streamflow-gaging stations in Texas-Continued

\begin{tabular}{|c|c|c|c|c|c|c|c|c|c|c|c|}
\hline \multirow{2}{*}{$\begin{array}{l}\text { USGS } \\
\text { station } \\
\text { no. } \\
\text { (pl. 1) }\end{array}$} & \multirow[t]{2}{*}{ Name } & \multirow[t]{2}{*}{$\begin{array}{c}\text { Status } \\
\text { as of } \\
10 / 01 / 99\end{array}$} & \multirow[t]{2}{*}{$\begin{array}{c}\text { Type } \\
\text { of } \\
\text { data }\end{array}$} & \multirow{2}{*}{$\begin{array}{l}\text { Record } \\
\text { length } \\
\text { (water } \\
\text { years }^{1} \text { ) }\end{array}$} & \multirow{2}{*}{$\begin{array}{c}\text { Regulation } \\
\text { condition } \\
\text { through } \\
1997\end{array}$} & \multirow{2}{*}{$\begin{array}{l}\text { Drainage } \\
\text { area } \\
\text { (square } \\
\text { miles) }\end{array}$} & \multirow{2}{*}{$\begin{array}{l}\text { Hydrologic } \\
\text { region } \\
\text { (fig. 3) }\end{array}$} & \multicolumn{4}{|c|}{$\begin{array}{c}\text { Major objective } \\
\text { of core } \\
\text { network met }\end{array}$} \\
\hline & & & & & & & & 1 & 2 & 3 & 4 \\
\hline 08086260 & Pecan Creek near Eolian, Tex. & $\mathrm{D}$ & $\mathrm{CR}$ & 9 & $\mathrm{U}$ & 26.4 & 3 & $\sqrt{ }$ & -- & -- & -- \\
\hline 08086290 & Big Sandy Creek above Breckenridge, Tex. & A & $\mathrm{CR}$ & 39 & $\mathrm{U}$ & 280 & 3 & $\checkmark$ & -- & -- & -- \\
\hline 08088000 & Brazos River near South Bend, Tex. & A & $\mathrm{CR}$ & 62 & $\mathrm{R}$ & 13,100 & 3 & -- & $\sqrt{ }$ & -- & -- \\
\hline 08088100 & Salt Creek at Olney, Tex. & $\mathrm{D}$ & $\mathrm{CR}$ & 20 & $\mathrm{U}$ & 11.8 & 3 & $\checkmark$ & -- & -- & -- \\
\hline 08088610 & Brazos River near Graford, Tex. & A & $\mathrm{CR}$ & 11 & $\mathrm{R}$ & 14,000 & 3 & -- & $\checkmark$ & -- & -- \\
\hline 08089000 & Brazos River near Palo Pinto, Tex. & A & $\mathrm{CR}$ & 77 & $\mathrm{R}$ & 14,200 & 3 & -- & $\sqrt{ }$ & -- & -- \\
\hline 08090800 & Brazos River near Dennis, Tex. & A & $\mathrm{CR}$ & 32 & $\mathrm{R}$ & 15,700 & 7 & -- & $\sqrt{ }$ & -- & -- \\
\hline 08091000 & Brazos River near Glen Rose, Tex. & A & $\mathrm{CR}$ & 77 & $\mathrm{R}$ & 16,300 & 7 & -- & $\sqrt{ }$ & -- & -- \\
\hline 08091500 & Paluxy River at Glen Rose, Tex. & A & $\mathrm{CR}$ & 53 & $\mathrm{R}$ & 410 & 7 & -- & -- & -- & $\checkmark$ \\
\hline 08093100 & Brazos River near Aquilla, Tex. & A & $\mathrm{CR}$ & 62 & $\mathrm{R}$ & 17,700 & 7 & -- & $\sqrt{ }$ & -- & -- \\
\hline${ }^{3} 08093250$ & Hackberry Creek at Hillsboro, Tex. & $\mathrm{D}$ & $\mathrm{CR}$ & 13 & $\mathrm{U}$ & 57.9 & 7 & $\checkmark$ & -- & -- & -- \\
\hline 08095200 & North Bosque River at Valley Mills, Tex. & A & $\mathrm{CR}$ & 41 & $\mathrm{R}$ & 1,150 & 7 & $\sqrt{ }$ & $\sqrt{ }$ & -- & -- \\
\hline 08096500 & Brazos River at Waco, Tex. & A & $\mathrm{CR}$ & 102 & $\mathrm{R}$ & 20,000 & 7 & -- & $\sqrt{ }$ & -- & -- \\
\hline 08098300 & Little Pond Creek near Burlington, Tex. & $\mathrm{D}$ & $\mathrm{CR}$ & 20 & $\mathrm{U}$ & 22.2 & 8 & $\sqrt{ }$ & -- & -- & -- \\
\hline 08099300 & Sabana River near De Leon, Tex. & A & PR & 40 & $\mathrm{U}$ & 264 & 4 & $\checkmark$ & -- & -- & -- \\
\hline 08100500 & Leon River at Gatesville, Tex. & A & $\mathrm{CR}$ & 50 & $\mathrm{R}$ & 2,340 & 4 & -- & $\sqrt{ }$ & -- & -- \\
\hline${ }^{2} 08101000$ & Cowhouse Creek at Pidcoke, Tex. & A & $\mathrm{CR}$ & 50 & $\mathrm{U}$ & 455 & 4 & $\checkmark$ & -- & -- & $\checkmark$ \\
\hline 08102500 & Leon River near Belton, Tex. & A & $\mathrm{CR}$ & 77 & $\mathrm{R}$ & 3,540 & 8 & -- & $\checkmark$ & -- & -- \\
\hline 08103800 & Lampasas River near Kempner, Tex. & A & $\mathrm{CR}$ & 38 & $\mathrm{R}$ & 818 & 4 & $\sqrt{ }$ & -- & -- & -- \\
\hline 08103900 & South Fork Rocky Creek near Briggs, Tex. & A & $\mathrm{CR}$ & 38 & $\mathrm{U}$ & 33.3 & 4 & $\sqrt{ }$ & -- & -- & -- \\
\hline 08104100 & Lampasas River near Belton, Tex. & A & $\mathrm{CR}$ & 29 & $\mathrm{R}$ & 1,320 & 8 & -- & $\sqrt{ }$ & -- & -- \\
\hline 08104500 & Little River near Little River, Tex. & A & $\mathrm{CR}$ & 43 & $\mathrm{R}$ & 5,230 & 8 & -- & $\sqrt{ }$ & -- & -- \\
\hline 08104700 & North Fork San Gabriel River near Georgetown, Tex. & A & $\mathrm{CR}$ & 32 & $\mathrm{R}$ & 248 & 8 & $\sqrt{ }$ & -- & -- & -- \\
\hline 08104900 & South Fork San Gabriel River at Georgetown, Tex. & A & $\mathrm{CR}$ & 33 & $\mathrm{U}$ & 133 & 8 & $\sqrt{ }$ & -- & -- & -- \\
\hline 08105100 & Berry Creek near Georgetown, Tex. & A & $\mathrm{CR}$ & 33 & $\mathrm{U}$ & 83.1 & 8 & $\sqrt{ }$ & -- & -- & -- \\
\hline 08106500 & Little River at Cameron, Tex. & $\mathrm{A}$ & $\mathrm{CR}$ & 83 & $\mathrm{R}$ & 7,070 & 8 & -- & $\sqrt{ }$ & -- & -- \\
\hline 08108200 & North Elm Creek near Cameron, Tex. & $\mathrm{D}$ & $\mathrm{CR}$ & 11 & $\mathrm{U}$ & 44.8 & 8 & $\checkmark$ & -- & -- & -- \\
\hline 08108700 & Brazos River at State Hwy. 21 near Bryan, Tex. & A & $\mathrm{CR}$ & 7 & $\mathrm{R}$ & 29,500 & 8 & -- & $\sqrt{ }$ & -- & -- \\
\hline${ }^{2} 08109700$ & Middle Yegua Creek near Dime Box, Tex. & A & $\mathrm{CR}$ & 38 & $\mathrm{U}$ & 236 & 8 & $\checkmark$ & -- & -- & $\checkmark$ \\
\hline 08109800 & East Yegua Creek near Dime Box, Tex. & A & $\mathrm{CR}$ & 38 & $\mathrm{U}$ & 244 & 8 & $\sqrt{ }$ & -- & -- & -- \\
\hline
\end{tabular}

Footnotes at end of table. 
Table 5. Core network of streamflow-gaging stations in Texas-Continued

\begin{tabular}{|c|c|c|c|c|c|c|c|c|c|c|c|}
\hline \multirow{2}{*}{$\begin{array}{c}\text { USGS } \\
\text { station } \\
\text { no. } \\
\text { (pl. 1) }\end{array}$} & \multirow[t]{2}{*}{ Name } & \multirow{2}{*}{$\begin{array}{l}\text { Status } \\
\text { as of } \\
10 / 01 / 99\end{array}$} & \multirow{2}{*}{$\begin{array}{l}\text { Type } \\
\text { of } \\
\text { data }\end{array}$} & \multirow{2}{*}{$\begin{array}{l}\text { Record } \\
\text { length } \\
\text { (water } \\
\text { years }^{1} \text { ) }\end{array}$} & \multirow{2}{*}{$\begin{array}{c}\text { Regulation } \\
\text { condition } \\
\text { through } \\
1997\end{array}$} & \multirow{2}{*}{$\begin{array}{l}\text { Drainage } \\
\text { area } \\
\text { (square } \\
\text { miles) }\end{array}$} & \multirow{2}{*}{$\begin{array}{l}\text { Hydrologic } \\
\text { region } \\
\text { (fig. 3) }\end{array}$} & \multicolumn{4}{|c|}{$\begin{array}{c}\text { Major objective } \\
\text { of core } \\
\text { network met }\end{array}$} \\
\hline & & & & & & & & 1 & 2 & 3 & 4 \\
\hline 08110100 & Davidson Creek near Lyons, Tex. & $\mathrm{A}$ & $\mathrm{CR}$ & 38 & $\mathrm{U}$ & 195 & 8 & $\sqrt{ }$ & -- & -- & -- \\
\hline 08110430 & Big Creek near Freestone, Tex. & $\mathrm{A}$ & $\mathrm{CR}$ & 22 & $\mathrm{U}$ & 97.2 & 7 & $\sqrt{ }$ & -- & -- & $\sqrt{ }$ \\
\hline 08110800 & Navasota River at Old San Antonio Road near Bryan, Tex. & A & $\mathrm{CR}$ & 3 & $\mathrm{R}$ & 1,290 & 8 & -- & $\checkmark$ & -- & -- \\
\hline 08111700 & Mill Creek near Bellville, Tex. & $\mathrm{D}$ & $\mathrm{CR}$ & 30 & $\mathrm{U}$ & 376 & 11 & $\sqrt{ }$ & -- & -- & -- \\
\hline 08114000 & Brazos River at Richmond, Tex. & A & $\mathrm{CR}$ & 82 & $\mathrm{R}$ & 35,400 & 11 & -- & $\checkmark$ & $\sqrt{ }$ & -- \\
\hline 08115000 & Big Creek near Needville, Tex. & A & $\mathrm{CR}$ & 53 & $\mathrm{U}$ & 42.8 & 11 & $\checkmark$ & -- & -- & -- \\
\hline 08116400 & Dry Creek near Rosenburg, Tex. & $\mathrm{D}$ & $\mathrm{CR}$ & 21 & $\mathrm{U}$ & 8.65 & 11 & $\sqrt{ }$ & -- & -- & -- \\
\hline${ }^{2} 08117500$ & San Bernard River near Boling, Tex. & A & $\mathrm{CR}$ & 46 & $\mathrm{U}$ & 727 & 11 & $\sqrt{ }$ & -- & $\sqrt{ }$ & $\sqrt{ }$ \\
\hline 08117995 & Colorado River near Gail, Tex. & A & $\mathrm{CR}$ & 12 & $\mathrm{U}$ & 498 & 3 & $\checkmark$ & -- & -- & -- \\
\hline 08121000 & Colorado River at Colorado City, Tex. & A & $\mathrm{CR}$ & 56 & $\mathrm{R}$ & 1,590 & 3 & -- & $\checkmark$ & -- & -- \\
\hline${ }^{3} 08121500$ & Morgan Creek near Westbrook, Tex. & $\mathrm{D}$ & $\mathrm{CR}$ & 9 & $\mathrm{U}$ & 230 & 3 & $\checkmark$ & -- & -- & -- \\
\hline 08123800 & Beals Creek near Westbrook, Tex. & A & $\mathrm{CR}$ & 42 & $\mathrm{U}$ & 1,990 & 3 & $\checkmark$ & $\checkmark$ & -- & -- \\
\hline 08123850 & Colorado River above Silver, Tex. & A & $\mathrm{CR}$ & 33 & $\mathrm{R}$ & 4,650 & 4 & -- & $\checkmark$ & -- & -- \\
\hline 08124000 & Colorado River at Robert Lee, Tex. & A & $\mathrm{CR}$ & 54 & $\mathrm{R}$ & 5,050 & 4 & $\sqrt{ }$ & $\sqrt{ }$ & -- & -- \\
\hline 08126380 & Colorado River near Ballinger, Tex. & A & $\mathrm{CR}$ & 93 & $\mathrm{R}$ & 6,110 & 4 & -- & $\checkmark$ & -- & -- \\
\hline${ }^{2} 08127000$ & Elm Creek at Ballinger, Tex. & A & $\mathrm{CR}$ & 68 & $\mathrm{R}$ & 450 & 4 & -- & -- & -- & $\checkmark$ \\
\hline 08128000 & South Concho River at Christoval, Tex. & A & PR & 70 & $\mathrm{U}$ & 413 & 4 & $\checkmark$ & -- & -- & -- \\
\hline 08128400 & Middle Concho River above Tankersley, Tex. & A & PR & 39 & $\mathrm{U}$ & 1,610 & 4 & $\checkmark$ & $\checkmark$ & -- & -- \\
\hline 08131400 & Pecan Creek near San Angelo, Tex. & $\mathrm{D}$ & $\mathrm{CR}$ & 25 & $\mathrm{U}$ & 81.1 & 4 & $\checkmark$ & -- & -- & -- \\
\hline${ }^{2} 08134000$ & North Concho River near Carlsbad, Tex. & A & $\mathrm{CR}$ & 76 & $\mathrm{U}$ & 1,190 & 4 & $\sqrt{ }$ & $\checkmark$ & -- & $\sqrt{ }$ \\
\hline 08136500 & Concho River at Paint Rock, Tex. & A & $\mathrm{CR}$ & 85 & $\mathrm{R}$ & 5,440 & 4 & -- & $\sqrt{ }$ & -- & -- \\
\hline 08136700 & Colorado River near Stacy, Tex. & A & $\mathrm{CR}$ & 32 & $\mathrm{R}$ & 12,800 & 4 & -- & $\sqrt{ }$ & -- & -- \\
\hline 08137500 & Mukewater Creek at Trickham, Tex. & $\mathrm{D}$ & $\mathrm{CR}$ & 23 & $\mathrm{R}$ & 70.0 & 4 & $\sqrt{ }$ & -- & -- & -- \\
\hline 08138000 & Colorado River at Winchell, Tex. & A & $\mathrm{CR}$ & 67 & $\mathrm{R}$ & 13,800 & 4 & -- & $\checkmark$ & -- & -- \\
\hline 08143600 & Pecan Bayou near Mullin, Tex. & A & $\mathrm{CR}$ & 33 & $\mathrm{R}$ & 2,070 & 4 & -- & $\checkmark$ & -- & -- \\
\hline 08144500 & San Saba River at Menard, Tex. & A & $\mathrm{CR}$ & 84 & $\mathrm{U}$ & 1,130 & 4 & $\checkmark$ & $\checkmark$ & -- & -- \\
\hline 08145000 & Brady Creek at Brady, Tex. & $\mathrm{D}$ & $\mathrm{CR}$ & 47 & $\mathrm{R}$ & 588 & 4 & $\checkmark$ & -- & -- & -- \\
\hline 08146000 & San Saba River at San Saba, Tex. & A & $\mathrm{CR}$ & 81 & $\mathrm{R}$ & 3,040 & 4 & -- & $\checkmark$ & -- & -- \\
\hline 08147000 & Colorado River near San Saba, Tex. & A & $\mathrm{CR}$ & 84 & $\mathrm{R}$ & 19,800 & 4 & -- & $\checkmark$ & -- & -- \\
\hline 08150000 & Llano River near Junction, Tex. & A & $\mathrm{CR}$ & 84 & $\mathrm{U}$ & 1,850 & 4 & $\checkmark$ & $\checkmark$ & -- & -- \\
\hline
\end{tabular}

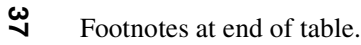


Table 5. Core network of streamflow-gaging stations in Texas-Continued

\begin{tabular}{|c|c|c|c|c|c|c|c|c|c|c|c|}
\hline \multirow{2}{*}{$\begin{array}{c}\text { USGS } \\
\text { station } \\
\text { no. } \\
\text { (pl. 1) }\end{array}$} & \multirow[t]{2}{*}{ Name } & \multirow{2}{*}{$\begin{array}{c}\text { Status } \\
\text { as of } \\
10 / 01 / 99\end{array}$} & \multirow{2}{*}{$\begin{array}{l}\text { Type } \\
\text { of } \\
\text { data }\end{array}$} & \multirow{2}{*}{$\begin{array}{l}\text { Record } \\
\text { length } \\
\text { (water } \\
\text { years }^{1} \text { ) }\end{array}$} & \multirow{2}{*}{$\begin{array}{c}\text { Regulation } \\
\text { condition } \\
\text { through } \\
1997\end{array}$} & \multirow{2}{*}{$\begin{array}{l}\text { Drainage } \\
\text { area } \\
\text { (square } \\
\text { miles) }\end{array}$} & \multirow{2}{*}{$\begin{array}{l}\text { Hydrologic } \\
\text { region } \\
\text { (fig. 3) }\end{array}$} & \multicolumn{4}{|c|}{$\begin{array}{c}\text { Major objective } \\
\text { of core } \\
\text { network met }\end{array}$} \\
\hline & & & & & & & & 1 & 2 & 3 & 4 \\
\hline 08150800 & Beaver Creek near Mason, Tex. & A & $\mathrm{CR}$ & 37 & $\mathrm{U}$ & 215 & 4 & $\sqrt{ }$ & -- & -- & -- \\
\hline${ }^{2} 08151500$ & Llano River at Llano, Tex. & A & $\mathrm{CR}$ & 61 & $\mathrm{U}$ & 4,190 & 4 & $\checkmark$ & $\checkmark$ & -- & $\sqrt{ }$ \\
\hline 08152000 & Sandy Creek near Kingsland, Tex. & A & $\mathrm{CR}$ & 33 & $\mathrm{U}$ & 346 & 4 & $\sqrt{ }$ & -- & -- & -- \\
\hline 08152900 & Pedernales River near Fredericksburg, Tex. & A & $\mathrm{CR}$ & 20 & $\mathrm{U}$ & 369 & 5 & $\checkmark$ & -- & -- & -- \\
\hline 08153500 & Pedernales River near Johnson City, Tex. & A & $\mathrm{CR}$ & 61 & $\mathrm{U}$ & 901 & 5 & $\sqrt{ }$ & -- & -- & -- \\
\hline 08154700 & Bull Creek at Loop 360 near Austin, Tex. & A & $\mathrm{CR}$ & 22 & $\mathrm{U}$ & 22.3 & 5 & $\sqrt{ }$ & -- & -- & -- \\
\hline 08155200 & Barton Creek at State Hwy. 71 near Oak Hill, Tex. & A & $\mathrm{CR}$ & 19 & $\mathrm{U}$ & 89.7 & 5 & $\sqrt{ }$ & -- & -- & -- \\
\hline 08158000 & Colorado River at Austin, Tex. & A & $\mathrm{CR}$ & 102 & $\mathrm{R}$ & 27,600 & 5 & -- & $\sqrt{ }$ & -- & -- \\
\hline 08158700 & Onion Creek near Driftwood, Tex. & A & $\mathrm{CR}$ & 21 & $\mathrm{U}$ & 124 & 5 & $\sqrt{ }$ & -- & -- & -- \\
\hline 08158810 & Bear Creek below FM 1826 near Driftwood, Tex. & A & $\mathrm{CR}$ & 22 & $\mathrm{U}$ & 12.2 & 5 & $\sqrt{ }$ & -- & -- & -- \\
\hline 08158840 & Slaughter Creek at FM 1826 near Austin, Tex. & A & $\mathrm{CR}$ & 23 & $\mathrm{U}$ & 8.24 & 5 & $\sqrt{ }$ & -- & -- & -- \\
\hline 08159000 & Onion Creek at U.S. Hwy. 183, Austin, Tex. & A & $\mathrm{CR}$ & 31 & $\mathrm{U}$ & 321 & 5 & -- & -- & -- & $\sqrt{ }$ \\
\hline${ }^{3} 08159150$ & Wilbarger Creek near Pflugerville, Tex. & $\mathrm{D}$ & $\mathrm{CR}$ & 17 & $\mathrm{U}$ & 4.61 & 8 & $\checkmark$ & -- & -- & -- \\
\hline 08159200 & Colorado River at Bastrop, Tex. & A & $\mathrm{CR}$ & 40 & $\mathrm{R}$ & 28,600 & 9 & -- & $\sqrt{ }$ & -- & -- \\
\hline 08160000 & Dry Creek at Buescher Lake near Smithville, Tex. & $\mathrm{D}$ & $\mathrm{CR}$ & 26 & $\mathrm{U}$ & 1.48 & 9 & $\sqrt{ }$ & -- & -- & -- \\
\hline 08160800 & Redgate Creek near Columbus, Tex. & A & $\mathrm{CR}$ & 39 & $\mathrm{U}$ & 17.3 & 9 & $\sqrt{ }$ & -- & -- & $\sqrt{ }$ \\
\hline 08161000 & Colorado River at Columbus, Tex. & A & $\mathrm{CR}$ & 85 & $\mathrm{R}$ & 30,200 & 9 & -- & $\checkmark$ & $\sqrt{ }$ & -- \\
\hline 08162600 & Tres Palacios River near Midfield, Tex. & A & $\mathrm{CR}$ & 29 & $\mathrm{U}$ & 145 & 9 & $\sqrt{ }$ & -- & -- & -- \\
\hline${ }^{2} 08164000$ & Lavaca River near Edna, Tex. & A & $\mathrm{CR}$ & 62 & $\mathrm{U}$ & 817 & 9 & $\sqrt{ }$ & -- & $\sqrt{ }$ & $\sqrt{ }$ \\
\hline${ }^{2} 08164300$ & Navidad River near Hallettsville, Tex. & A & $\mathrm{CR}$ & 39 & $\mathrm{U}$ & 332 & 9 & $\sqrt{ }$ & -- & -- & $\sqrt{ }$ \\
\hline 08164390 & Navidad River at Strane Park near Edna, Tex. & A & $\mathrm{CR}$ & 4 & $\mathrm{U}$ & 579 & 9 & $\sqrt{ }$ & -- & $\sqrt{ }$ & -- \\
\hline 08164450 & Sandy Creek near Ganado, Tex. & A & $\mathrm{CR}$ & 23 & $\mathrm{U}$ & 289 & 9 & $\sqrt{ }$ & -- & -- & -- \\
\hline 08164503 & West Mustang Creek near Ganado, Tex. & A & $\mathrm{CR}$ & 23 & $\mathrm{U}$ & 178 & 9 & $\sqrt{ }$ & -- & -- & -- \\
\hline 08164504 & East Mustang Creek at FM 647 near Louise, Tex. & A & $\mathrm{CR}$ & 4 & $\mathrm{U}$ & 90.8 & 9 & $\sqrt{ }$ & -- & -- & -- \\
\hline 08164600 & Garcitas Creek near Inez, Tex. & A & $\mathrm{CR}$ & 30 & $\mathrm{U}$ & 91.7 & 9 & $\sqrt{ }$ & -- & -- & -- \\
\hline 08164800 & Placedo Creek near Placedo, Tex. & A & $\mathrm{CR}$ & 30 & $\mathrm{U}$ & 68.3 & 9 & $\checkmark$ & -- & -- & -- \\
\hline 08165300 & North Fork Guadalupe River near Hunt, Tex. & A & $\mathrm{CR}$ & 33 & $\mathrm{U}$ & 168 & 5 & $\sqrt{ }$ & -- & -- & -- \\
\hline 08165500 & Guadalupe River at Hunt, Tex. & A & $\mathrm{CR}$ & 35 & $\mathrm{U}$ & 288 & 5 & $\checkmark$ & -- & -- & -- \\
\hline 08166200 & Guadalupe River at Kerrville, Tex. & A & $\mathrm{CR}$ & 15 & $\mathrm{U}$ & 510 & 5 & $\sqrt{ }$ & -- & -- & -- \\
\hline${ }^{2} 08167000$ & Guadalupe River at Comfort, Tex. & $\mathrm{A}$ & $\mathrm{CR}$ & 62 & $\mathrm{U}$ & 839 & 5 & $\checkmark$ & -- & -- & $\sqrt{ }$ \\
\hline
\end{tabular}


Table 5. Core network of streamflow-gaging stations in Texas-Continued

\begin{tabular}{|c|c|c|c|c|c|c|c|c|c|c|c|}
\hline \multirow{2}{*}{$\begin{array}{c}\text { USGS } \\
\text { station } \\
\text { no. } \\
\text { (pl. 1) }\end{array}$} & \multirow[t]{2}{*}{ Name } & \multirow{2}{*}{$\begin{array}{c}\text { Status } \\
\text { as of } \\
10 / 01 / 99\end{array}$} & \multirow{2}{*}{$\begin{array}{l}\text { Type } \\
\text { of } \\
\text { data }\end{array}$} & \multirow{2}{*}{$\begin{array}{l}\text { Record } \\
\text { length } \\
\text { (water } \\
\text { years }^{1} \text { ) }\end{array}$} & \multirow{2}{*}{$\begin{array}{c}\text { Regulation } \\
\text { condition } \\
\text { through } \\
1997\end{array}$} & \multirow{2}{*}{$\begin{array}{l}\text { Drainage } \\
\text { area } \\
\text { (square } \\
\text { miles) }\end{array}$} & \multirow{2}{*}{$\begin{array}{l}\text { Hydrologic } \\
\text { region } \\
\text { (fig. 3) }\end{array}$} & \multicolumn{4}{|c|}{$\begin{array}{c}\text { Major objective } \\
\text { of core } \\
\text { network met }\end{array}$} \\
\hline & & & & & & & & 1 & 2 & 3 & 4 \\
\hline 08167500 & Guadalupe River near Spring Branch, Tex. & A & $\mathrm{CR}$ & 78 & $\mathrm{U}$ & 1,320 & 5 & $\sqrt{ }$ & $\checkmark$ & -- & -- \\
\hline 08167600 & Rebecca Creek near Spring Branch, Tex. & $\mathrm{D}$ & $\mathrm{CR}$ & 19 & $\mathrm{R}$ & 10.9 & 5 & $\checkmark$ & -- & -- & -- \\
\hline 08168500 & Guadalupe River above Comal River at New Braunfels, Tex. & A & $\mathrm{CR}$ & 73 & $\mathrm{R}$ & 1,520 & 5 & -- & $\checkmark$ & -- & -- \\
\hline 08169000 & Comal River at New Braunfels, Tex. & A & $\mathrm{CR}$ & 63 & $\mathrm{R}$ & 130 & 5 & -- & $\sqrt{ }$ & -- & -- \\
\hline 08171000 & Blanco River at Wimberley, Tex. & A & $\mathrm{CR}$ & 74 & $\mathrm{U}$ & 355 & 5 & $\checkmark$ & -- & -- & -- \\
\hline 08172000 & San Marcos River at Luling, Tex. & A & $\mathrm{CR}$ & 61 & $\mathrm{R}$ & 838 & 9 & -- & -- & -- & $\sqrt{ }$ \\
\hline 08175000 & Sandies Creek near Westhoff, Tex. & A & $\mathrm{CR}$ & 45 & $\mathrm{U}$ & 549 & 9 & $\checkmark$ & -- & -- & -- \\
\hline${ }^{2} 08176500$ & Guadalupe River at Victoria, Tex. & A & $\mathrm{CR}$ & 66 & $\mathrm{R}$ & 5,200 & 9 & -- & $\checkmark$ & $\sqrt{ }$ & -- \\
\hline 08176900 & Coleto Creek at Arnold Rd. near Schroeder, Tex. & A & $\mathrm{CR}$ & 22 & $\mathrm{U}$ & 357 & 9 & $\checkmark$ & -- & -- & $\sqrt{ }$ \\
\hline 08177300 & Perdido Creek at FM 622 near Fannin, Tex. & A & PR & 22 & $\mathrm{U}$ & 28.0 & 9 & $\checkmark$ & -- & -- & -- \\
\hline 08177500 & Coleto Creek near Victoria, Tex. & A & $\mathrm{CR}$ & 38 & $\mathrm{R}$ & 514 & 9 & $\sqrt{ }$ & -- & -- & -- \\
\hline 08178880 & Medina River at Bandera, Tex. & A & $\mathrm{CR}$ & 18 & $\mathrm{U}$ & 427 & 5 & $\checkmark$ & -- & -- & -- \\
\hline 08181400 & Helotes Creek at Helotes, Tex. & A & $\mathrm{CR}$ & 32 & $\mathrm{U}$ & 15.0 & 5 & $\checkmark$ & -- & -- & -- \\
\hline 08181500 & Medina River at San Antonio, Tex. & A & $\mathrm{CR}$ & 61 & $\mathrm{R}$ & 1,320 & 5 & -- & $\sqrt{ }$ & -- & -- \\
\hline 08183500 & San Antonio River near Falls City, Tex. & A & $\mathrm{CR}$ & 75 & $\mathrm{R}$ & 2,110 & 9 & -- & $\checkmark$ & -- & -- \\
\hline${ }^{2} 08186000$ & Cibilo Creek near Falls City, Tex. & A & $\mathrm{CR}$ & 70 & $\mathrm{U}$ & 827 & 9 & $\checkmark$ & -- & -- & $\sqrt{ }$ \\
\hline 08188500 & San Antonio River at Goliad, Tex. & A & $\mathrm{CR}$ & 67 & $\mathrm{R}$ & 3,920 & 9 & -- & $\checkmark$ & $\sqrt{ }$ & -- \\
\hline${ }^{5} 08188800$ & Guadalupe River near Tivoli, Tex. & A & $\mathrm{CR}$ & 34 & $\mathrm{R}$ & 10,100 & 9 & -- & $\checkmark$ & $\sqrt{ }$ & -- \\
\hline 08189200 & Copano Creek near Refugio, Tex. & A & $\mathrm{CR}$ & 30 & $\mathrm{U}$ & 87.8 & 9 & $\checkmark$ & -- & -- & -- \\
\hline${ }^{3} 08189300$ & Medio Creek near Beeville, Tex. & $\mathrm{D}$ & $\mathrm{CR}$ & 16 & $\mathrm{U}$ & 204 & 9 & $\checkmark$ & -- & -- & -- \\
\hline${ }^{2} 08189500$ & Misson River at Refugio, Tex. & A & $\mathrm{CR}$ & 61 & $\mathrm{U}$ & 690 & 9 & $\checkmark$ & -- & $\sqrt{ }$ & $\sqrt{ }$ \\
\hline${ }^{2} 08189700$ & Aransas River near Skidmore, Tex. & A & $\mathrm{CR}$ & 37 & $\mathrm{U}$ & 247 & 9 & $\checkmark$ & -- & $\sqrt{ }$ & -- \\
\hline 08190000 & Nueces River at Laguna, Tex. & A & $\mathrm{CR}$ & 78 & $\mathrm{U}$ & 737 & 5 & $\checkmark$ & -- & -- & -- \\
\hline${ }^{2} 08190500$ & West Nueces River near Brackettville, Tex. & A & $\mathrm{CR}$ & 55 & $\mathrm{U}$ & 694 & 5 & $\sqrt{ }$ & -- & -- & $\checkmark$ \\
\hline 08192000 & Nueces River below Uvalde, Tex. & A & $\mathrm{CR}$ & 73 & $\mathrm{U}$ & 1,860 & 5 & $\checkmark$ & $\sqrt{ }$ & -- & -- \\
\hline 08194000 & Nueces River at Cotulla, Tex. & A & $\mathrm{CR}$ & 77 & $\mathrm{R}$ & 5,170 & 6 & -- & $\checkmark$ & -- & -- \\
\hline 08194200 & San Casimiro Creek near Freer, Tex. & A & $\mathrm{CR}$ & 39 & $\mathrm{U}$ & 469 & 6 & $\checkmark$ & -- & -- & -- \\
\hline 08194500 & Nueces River near Tilden, Tex. & A & $\mathrm{CR}$ & 59 & $\mathrm{R}$ & 8,090 & 6 & -- & $\checkmark$ & -- & $\checkmark$ \\
\hline 08195000 & Frio River at Concan, Tex. & A & $\mathrm{CR}$ & 75 & $\mathrm{U}$ & 389 & 5 & $\checkmark$ & -- & -- & -- \\
\hline 08196000 & Dry Frio River near Reagan Wells, Tex. & A & $\mathrm{CR}$ & 48 & $\mathrm{U}$ & 126 & 5 & $\checkmark$ & -- & -- & -- \\
\hline
\end{tabular}


Table 5. Core network of streamflow-gaging stations in Texas-Continued

\begin{tabular}{|c|c|c|c|c|c|c|c|c|c|c|c|}
\hline \multirow{2}{*}{$\begin{array}{l}\text { USGS } \\
\text { station } \\
\text { no. } \\
\text { (pl. 1) }\end{array}$} & \multirow[t]{2}{*}{ Name } & \multirow{2}{*}{$\begin{array}{c}\text { Status } \\
\text { as of } \\
10 / 01 / 99\end{array}$} & \multirow{2}{*}{$\begin{array}{l}\text { Type } \\
\text { of } \\
\text { data }\end{array}$} & \multirow{2}{*}{$\begin{array}{l}\text { Record } \\
\text { length } \\
\text { (water } \\
\text { years }^{1} \text { ) }\end{array}$} & \multirow{2}{*}{$\begin{array}{c}\text { Regulation } \\
\text { condition } \\
\text { through } \\
1997\end{array}$} & \multirow{2}{*}{$\begin{array}{l}\text { Drainage } \\
\text { area } \\
\text { (square } \\
\text { miles) }\end{array}$} & \multirow{2}{*}{$\begin{array}{l}\text { Hydrologic } \\
\text { region } \\
\text { (fig. 3) }\end{array}$} & \multicolumn{4}{|c|}{$\begin{array}{c}\text { Major objective } \\
\text { of core } \\
\text { network met }\end{array}$} \\
\hline & & & & & & & & 1 & 2 & 3 & 4 \\
\hline 08197500 & Frio River below Dry Frio River near Uvalde, Tex. & $\mathrm{A}$ & $\mathrm{CR}$ & 49 & $\mathrm{U}$ & 631 & 5 & $\sqrt{ }$ & -- & -- & -- \\
\hline 08198000 & Sabinal River near Sabinal, Tex. & A & $\mathrm{CR}$ & 58 & $\mathrm{U}$ & 206 & 5 & $\sqrt{ }$ & -- & -- & -- \\
\hline 08198500 & Sabinal River at Sabinal, Tex. & A & $\mathrm{CR}$ & 48 & $\mathrm{U}$ & 241 & 5 & $\sqrt{ }$ & -- & -- & -- \\
\hline 08200000 & Hondo Creek near Tarpley, Tex. & A & $\mathrm{CR}$ & 48 & $\mathrm{U}$ & 95.6 & 5 & $\sqrt{ }$ & -- & -- & -- \\
\hline 08200700 & Hondo Creek at King Waterhole near Hondo, Tex. & A & $\mathrm{CR}$ & 39 & $\mathrm{U}$ & 149 & 5 & $\checkmark$ & -- & -- & -- \\
\hline 08201500 & Seco Creek at Miller Ranch near Utopia, Tex. & A & $\mathrm{CR}$ & 39 & $\mathrm{U}$ & 45.0 & 5 & $\sqrt{ }$ & -- & -- & -- \\
\hline 08202700 & Seco Creek at Rowe Ranch near D'Hanis, Tex. & A & $\mathrm{CR}$ & 39 & $\mathrm{U}$ & 168 & 5 & $\sqrt{ }$ & -- & -- & -- \\
\hline${ }^{2} 08205500$ & Frio River near Derby, Tex. & A & $\mathrm{CR}$ & 85 & $\mathrm{U}$ & 3,430 & 6 & $\checkmark$ & $\sqrt{ }$ & -- & $\sqrt{ }$ \\
\hline 08206700 & San Miguel Creek near Tilden, Tex. & A & $\mathrm{CR}$ & 37 & $\mathrm{U}$ & 783 & 6 & $\sqrt{ }$ & -- & -- & -- \\
\hline${ }^{2} 08208000$ & Atascosa River at Whitsett, Tex. & A & $\mathrm{CR}$ & 70 & $\mathrm{U}$ & 1,170 & 6 & $\checkmark$ & $\checkmark$ & -- & $\sqrt{ }$ \\
\hline 08210400 & Lagarto Creek near George West, Tex. & $\mathrm{D}$ & $\mathrm{CR}$ & 17 & $\mathrm{U}$ & 155 & 6 & $\checkmark$ & -- & -- & -- \\
\hline 08211000 & Nueces River near Mathis, Tex. & A & $\mathrm{CR}$ & 61 & $\mathrm{R}$ & 16,700 & 6 & -- & $\checkmark$ & $\sqrt{ }$ & -- \\
\hline 08211520 & Oso Creek at Corpus Christi, Tex. & A & $\mathrm{CR}$ & 28 & $\mathrm{U}$ & 90.3 & 6 & $\checkmark$ & -- & -- & -- \\
\hline 08211900 & San Fernando Creek at Alice, Tex. & A & $\mathrm{CR}$ & 25 & $\mathrm{R}$ & 507 & 6 & -- & -- & $\sqrt{ }$ & $\sqrt{ }$ \\
\hline 08212400 & Los Olmos Creek near Falfurrias, Tex. & A & $\mathrm{CR}$ & 19 & $\mathrm{U}$ & 476 & 6 & $\sqrt{ }$ & -- & $\sqrt{ }$ & $\sqrt{ }$ \\
\hline${ }^{6} 08374000$ & Alamito Creek near Presidio, Tex. & A & PR & 68 & $\mathrm{U}$ & 1,500 & 2 & $\sqrt{ }$ & $\checkmark$ & -- & $\sqrt{ }$ \\
\hline${ }^{6} 08374500$ & Terlingua Creek near Terlingua, Tex. & A & PR & 68 & $\mathrm{U}$ & 1,070 & 2 & $\sqrt{ }$ & $\checkmark$ & -- & $\sqrt{ }$ \\
\hline 08376300 & Sanderson Canyon at Sanderson, Tex. & $\mathrm{D}$ & $\mathrm{CR}$ & 12 & $\mathrm{U}$ & 195 & 2 & $\sqrt{ }$ & -- & -- & -- \\
\hline 08408500 & Delaware River near Red Bluff, NM & A & $\mathrm{CR}$ & 62 & $\mathrm{U}$ & 689 & 2 & $\sqrt{ }$ & -- & -- & $\sqrt{ }$ \\
\hline${ }^{3} 08412500$ & Pecos River near Orla, Tex. & $\mathrm{D}$ & $\mathrm{CR}$ & 60 & $\mathrm{R}$ & 21,200 & 2 & -- & $\checkmark$ & -- & -- \\
\hline 08431700 & Limpia Creek above Fort Davis, Tex. & $\mathrm{D}$ & $\mathrm{CR}$ & 21 & $\mathrm{U}$ & 52.4 & 2 & $\checkmark$ & -- & -- & -- \\
\hline 08433000 & Barrilla Draw near Saragosa, Tex. & $\mathrm{D}$ & $\mathrm{CR}$ & 8 & $\mathrm{U}$ & 612 & 2 & $\sqrt{ }$ & -- & -- & -- \\
\hline 08435700 & Sunny Glen Canyon near Alpine, Tex. & $\mathrm{D}$ & $\mathrm{CR}$ & 9 & $\mathrm{U}$ & 29.7 & 2 & $\sqrt{ }$ & -- & -- & -- \\
\hline 08446500 & Pecos River near Girvin, Tex. & A & $\mathrm{CR}$ & 61 & $\mathrm{R}$ & 29,600 & 2 & -- & $\checkmark$ & -- & $\sqrt{ }$ \\
\hline${ }^{6} 08449400$ & Devils River at Pafford Crossing near Comstock, Tex. & A & PR & 41 & $\mathrm{U}$ & 3,960 & 2 & $\sqrt{ }$ & $\checkmark$ & -- & $\checkmark$ \\
\hline
\end{tabular}

${ }^{6} 08449400$ Devils River at Pafford Crossing near Comstock, Tex.

year ending September 30, 1999, is water year 1999

${ }^{2}$ Station identified as too important to exclude from regional optimization model.

${ }^{3}$ Station excluded from minimum core network.

${ }^{4}$ Station 08072050 San Jacinto River near Sheldon gages outflow from San Jacinto River. It is likely that daily streamflow cannot be gaged at this station because of effects from tides. In that case, station 08071000, Peach Creek at Splendora, can be used to estimate total flow into Lake Houston, which could represent outflow from the basin

${ }^{5}$ Maximum gage heights upstream and downstream from saltwater barrier.

${ }^{6}$ Station currently operated by International Boundary and Water Commission, thus not used in optimization model. 
District Chief

U.S. Geological Survey

8027 Exchange Dr.

Austin, TX 78754-4733 